\title{
A systematic search for downstream mediators of tumor suppressor function of p53 reveals a major role of BTG2 in suppression of Ras-induced transformation
}

\author{
Alexander D. Boiko, ${ }^{1,3}$ Sarah Porteous, ${ }^{2}$ Olga V. Razorenova, ${ }^{1}$ Vadim I. Krivokrysenko, ${ }^{1,4}$ \\ Bryan R. Williams, ${ }^{2}$ and Andrei V. Gudkov ${ }^{1,4,5}$ \\ ${ }^{1}$ Department of Molecular Genetics and ${ }^{2}$ Department of Cancer Biology, Lerner Research Institute, Cleveland Clinic \\ Foundation, Cleveland, Ohio 44195, USA; ${ }^{3}$ Department of Biochemistry and Molecular Genetics, University of Illinois at \\ Chicago, Chicago, Illinois 60607, USA; ${ }^{4}$ Cleveland BioLabs, Inc., Cleveland, Ohio 44106, USA
}

\begin{abstract}
Factors that mediate p53 tumor suppressor activity remain largely unknown. In this study we describe a systematic approach to identify downstream mediators of tumor suppressor function of p53, consisting of global gene expression profiling, focused short hairpin RNA (shRNA) library creation, and functional selection of genetic elements cooperating with oncogenic Ras in cell transformation. This approach is based on our finding that repression of gene expression is a major event, occurring in response to p53 inactivation during transformation and immortalization of primary cells. Functional analysis of the subset of genes universally down-regulated in the cells that lacked functional p53 revealed BTG2 as a major downstream effector of p53-dependent proliferation arrest of mouse and human fibroblasts transduced with oncogenic Ras. shRNA-mediated knockdown of BTG2 cooperates with oncogenic Ras to transform primary mouse fibroblasts containing wild-type transcriptionally active p53. Repression of BTG2 results in up-regulation of cyclins D1 and $\mathrm{E} 1$ and phosphorylation of $\mathrm{Rb}$ and, in cooperation with other oncogenic elements, induces neoplastic transformation of primary human fibroblasts. BTG2 expression was found to be significantly reduced in a large proportion of human kidney and breast carcinomas, suggesting that BTG2 is a tumor suppressor that links $\mathbf{p} 53$ and $\mathrm{Rb}$ pathways in human tumorigenesis.
\end{abstract}

[Keywords: BTG2; Rb; oncogenic Ras; p53; shRNA library; tumor suppressor gene]

Received September 6, 2005; revised version accepted November 28, 2005.

Malignant transformation results from the gradual acquisition of mutations deregulating two categories of genes: proto-oncogenes and tumor suppressor genes, which are normally involved in positive and negative control of cell proliferation, respectively (Hunter 1997). Frequently, activation of an oncogene requires acquisition of additional genetic alteration of another gene that naturally serves to prevent expansion of such cell, a phenomenon known as cooperation of genetic events in malignant transformation (Land et al. 1983; Newbold and Overell 1983). This concept, originally based on the studies of primary rodent fibroblasts transformed by the combination of oncogenes Ras and Myc (Land et al. 1983;

${ }^{5}$ Corresponding author.

E-MAIL gudkov@ccf.org; FAX (216) 444-0512.

Article and publication are at http://www.genesdev.org/cgi/doi/10.1101/ gad.1372606.
Ruley 1983), which were thought to induce transformation and immortalization, respectively, was then extended to several combinations of genetic events, some of which are sufficient to transform human fibroblasts (Hahn and Weinberg 2002). All of them, however, involve activation of Ras and inactivation of $\mathrm{p} 53$ pathways, thus reflecting the critical importance of these two regulatory networks for cell proliferation and the tight interconnection between them. It is therefore no surprise that the inactivation of p53 and mutations in members of the Ras family of proto-oncogenes are among the most common events found in human cancers (Bos 1989; Levine 1997).

In fact, oncogenic Ras is incapable of transforming primary fibroblasts by itself, instead inducing growth arrest and premature senescence (Franza et al. 1986; Serrano et al. 1997). This arrest results from Ras-dependent transcriptional activation of $\mathrm{p} 19^{\mathrm{ARF}}$ that disrupts p53:MDM2 
interaction, leading to stabilization and accumulation of transcriptionally active p53, which blocks cell proliferation (Palmero et al. 1998; Sherr 1998). Hence, during Ras-mediated transformation of mouse or rat fibroblasts, senescence-like growth arrest can be overcome by inactivation of p19 ARF or p53 (Finlay et al. 1989; Kamijo et al. 1997). However, what is sufficient for the acquisition of a fully transformed tumorigenic phenotype in rodent cells is not paralleled by human counterparts, which in addition to p53 inactivation must overcome $\mathrm{Rb}$-mediated arrest of proliferation during the process of complete neoplastic transformation (Hahn et al. 1999).

Since functional inactivation of p53 is essential for Ras-mediated transformation in both cell systems, identification of downstream executors of p53-mediated growth arrest in response to activated Ras is critically important to understanding the mechanisms of tumor suppression. Stabilization and activation of p53 in response to oncogenic signaling leads to growth arrest (Serrano et al. 1997; Lin et al. 1998) or induction of apoptosis (Debbas and White 1993; Hermeking and Eick 1994). While molecular events acting upstream of p53, including those that are involved in regulation of p19 ${ }^{\mathrm{ARF}}$, are quite well studied and their direct role in cell transformation is now established (Jacobs et al. 1999; Inoue et al. 2000), downstream factors mediating p53 tumor suppressive function remain largely unknown. Recently, it has been suggested that inhibition of proapoptotic function of p53 through reduced expression of its downstream targets, such as bax and puma, or overexpression of bcl-2 and $\mathrm{bcl}_{\mathrm{XL}}$ can promote tumorigenesis in vivo (Yin et al. 1997; Hemann et al. 2004; Lowe et al. 2004); however, deregulation of any of those genes cannot substitute for p53 loss in their ability to cooperate directly with Ras in transformation of primary cells.

In the current study we approached this problem by combining comprehensive microarray profiling of Rasinduced transformation with short hairpin RNA (shRNA) library screening to identify the genes that are responsible for p53-mediated suppression of transformation. As a result, we found that suppression of immediate early growth response gene, BTG2 (Bradbury et al. 1991; Varnum et al. 1991) was sufficient for Ras-induced oncogenic transformation of primary murine fibroblasts possessing transcriptionally active p53. shRNA-mediated knockdown of BTG2 results in hyperphosphorylation of $\mathrm{Rb}$ and cooperates with p53 inhibitor GSE56, small t-antigen of SV40, and catalytic subunit of H-TERT in transformation of human primary fibroblasts. Additionally, we determined that BTG2 expression is reduced in significant proportion of patients with kidney, breast, and to a lesser extent, stomach carcinomas.

\section{Results}

\section{Establishment of experimental system}

The approach we used to identify candidate genes mediating p53 tumor suppressor activity is outlined in Figure 1:
Inactivation of p53 makes mouse embryo fibroblasts (MEFs) fully permissive for Ras-induced transformation (Finlay et al. 1989); thus, we presumed that inactivation of critical components of the p53 pathway, acting downstream of p53 in response to oncogenic Ras, should be functionally equivalent to inactivation of p53 itself and permit full transformation of rodent fibroblasts. To identify such genes, we have compared microarray profiles of p53-deficient immortalized and Ras-transformed MEFs. After determining that repression, rather than activation, was a governing factor regulating expression of the candidate genes, we created a set of shRNAs specific for the selected group of these genes and screened it in combination with oncogenic Ras for the clones capable of transforming primary MEFs. At this stage of the screening, we considered mouse cells as a simplified experimental model of oncogenic transformation where the number of required cooperating factors is minimal in contrast with the human cells, which possess multiple tumor suppressive pathways to prevent tumorigenesis during much longer life span. Therefore, the next step of our study was to determine the involvement of the identified factors in human transformation and their expression in human tumors.

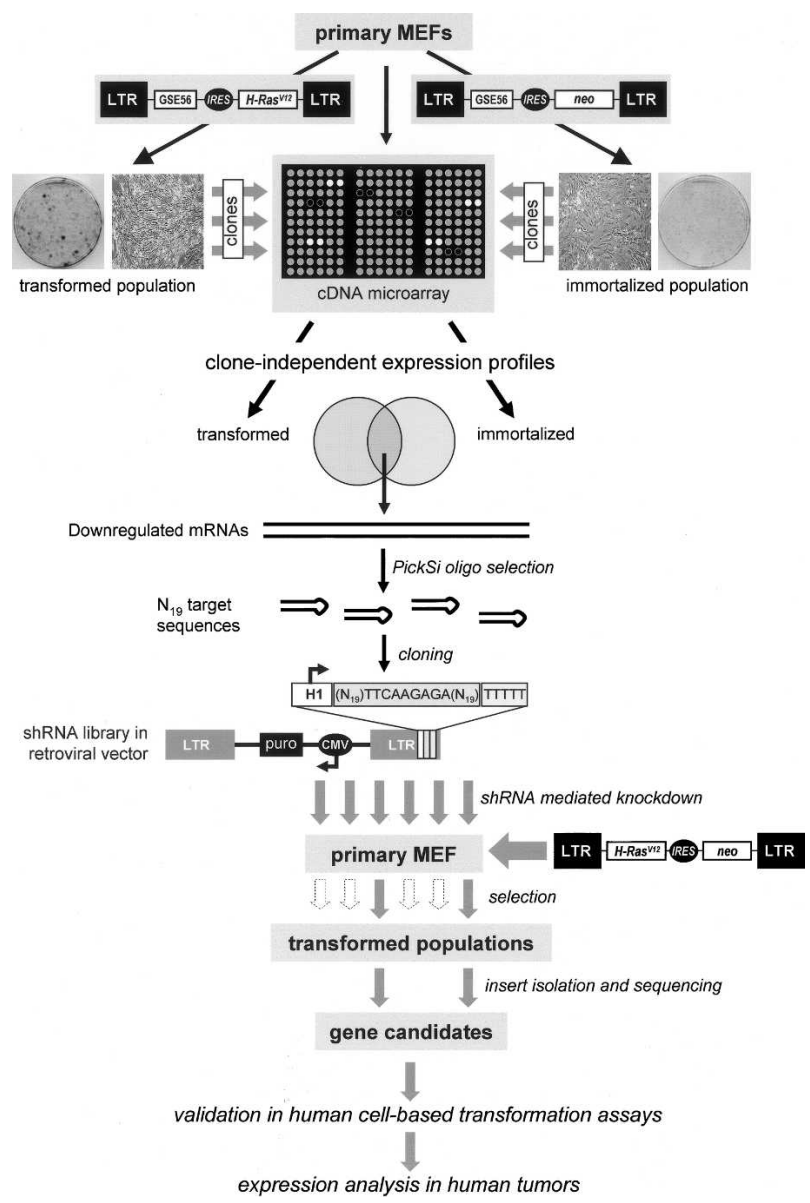

Figure 1. General outline of the study. See the explanation in the text. 
In principle, to identify genetic alterations underlying the effect of p53 inhibition in murine cells, one could compare gene expression profiles of MEFs from wildtype and p53-deficient mice. However, the major disadvantages of such a system involve possible adaptive changes in gene expression acquired during the development of p53-knockout mice and a high degree of genomic instability of $\mathrm{p} 53^{-/-}$cells that may greatly affect individual gene expression patterns of cell clones. At the same time, expression profiling of Ras-mediated cell transformation can only be carried out in cells that have lost functional p53. To overcome these problems, we have constructed a retroviral vector pL56_IRES_RAS that coexpresses oncogenic $\mathrm{H}-\mathrm{Ras}^{\mathrm{v} 12}$ together with the powerful dominant-negative p53 inhibitor GSE56 (Ossovskaya et al. 1996) and allows oncogenic transformation of primary cells, which can be then compared with the parental cell population to determine genetic changes accompanying this process. We next demonstrated that retroviral transduction of MEFs with pL56_IRES_RAS leads to the establishment of morphologically transformed cultures, while expression of GSE56 alone caused effective immortalization of MEFs.

Complete transformation of MEFs is associated with unlimited proliferative capacity, low sensitivity to growth factor withdrawal, reduced contact inhibition leading to formation of multilayered cultures, anchorage independence, and tumorigenicity (Reddy et al. 1982;
Seeburg et al. 1984; Greig et al. 1985; Zhan and Goldfarb 1986). To identify genetic changes associated with the initiation of neoplastic growth that are preserved throughout the entire process of transformation, we generated a set of clonal MEF cultures that includes variants of a complete or incomplete tumorigenic phenotype (Fig. $2)$. Thus, we generated four phenotypically different transformed clonal cultures (56R1, 56R2, 56R4, 56R7) established from individual transformed colonies infected with retroviral vector encoding GSE56_RAS (Fig. 2A). MEFs infected with GSE56 alone were represented by two cell cultures $(56 \mathrm{SN} 1,56 \mathrm{SN} 5)$ derived from two independent immortalized clones. These cell lines were compared with a population of MEFs transduced with control vector. Western blot analysis confirmed that all transformed cultures expressed various levels of oncogenic Ras (Fig. 2B), resulting in substantial differences of cyclin D1 induction. Establishment of H-Ras ${ }^{\mathrm{v} 12}$ transformation was also associated with increased expression of the p53 inhibitor, GSE56, as compared with cell cultures not exposed to oncogenic Ras, presumably because of a less strict requirement for p53 suppression (Serrano et al. 1997). Ras-transformed cultures were all characterized by rapid proliferation and low sensitivity to serum withdrawal (Fig. 2C). As opposed to parental and immortalized cell populations, the majority of Ras-transduced clones were capable of anchorage-independent growth, although this property correlated with relative levels of Ras expression among the four clones used: Clone 56R2
Figure 2. Subcloning and selection of cell cultures with properties of complete neoplastic transformation. (A) Cell morphology at day 14 after MEFs were transduced with indicated constructs and randomly subcloned into cell subcultures for further analysis of their properties. (B) Western blots of cellular lysates that indicate expression levels of GSE56, oncogenic Ras and its downstream target cyclin D1 in described cell cultures. $(C)$ Doubling time and growth factor dependence of MEFs infected with GSE56 (clones 56SN1, 56SN5), GSE56-IRES-Ras (clones 56R1, 56R2, 56R4, 56R7) and with EGFP. $(D)$ Growth of indicated MEF cell subcultures in the absence of anchorage support. $(E)$ Ability of indicated cell subcultures to form tumors in vivo. Cells $\left(5 \times 10^{6}\right)$ were injected into athymic nu/nu mice. Twenty-four days later mice were sacrificed and tumors were weighed.
A

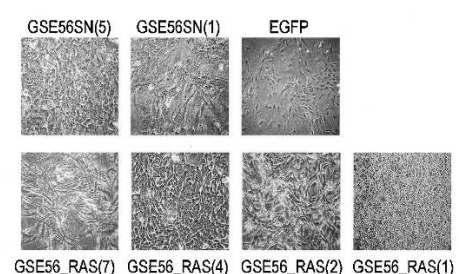

C

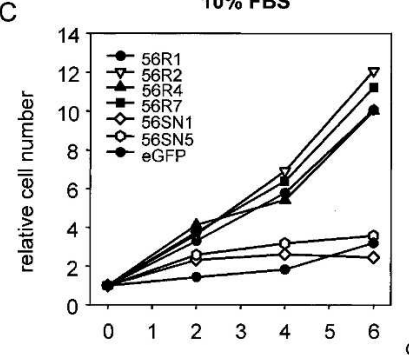

D

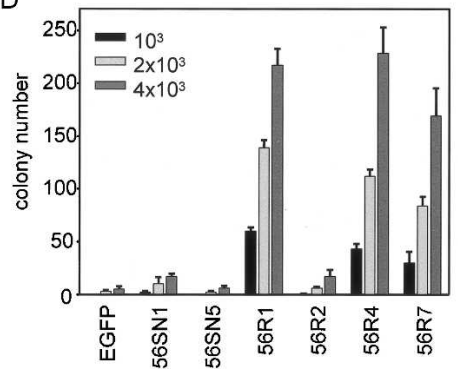

B

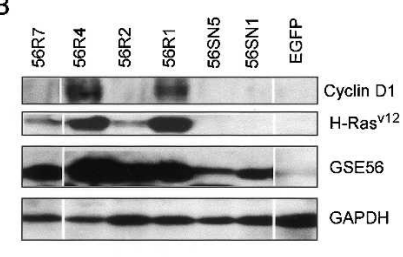

$1 \%$ FBS

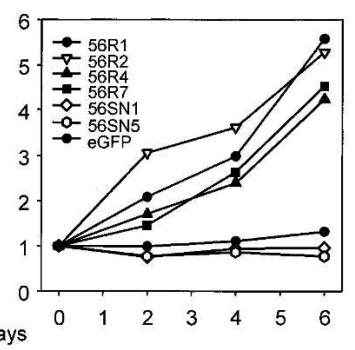

$E$

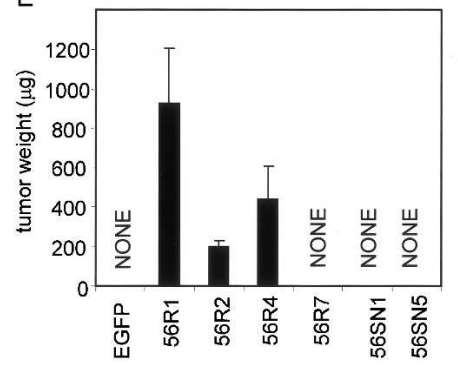


was not able to grow at all under these condition, while 56R7 produced a lower number of colonies than 56R1 and 56R4 (Fig. 2D). Anchorage independence correlated well with tumorigenicity of MEF cultures as assessed by their ability to form tumors following subcutaneous injection in athymic nu/nu mice: 56R 1 and 56R 4 were highly tumorigenic, while $56 \mathrm{R} 2$ produced much smaller tumors and 56R7 was unable to yield any detectable tumor growth similar to immortalized and control cell populations (Fig. 2E). In summary, a strong correlation was determined between the high levels of expression of oncogenic Ras, its downstream target cyclin D1, and tumorigenicity of transformed MEFs.

Characterization of individual clones of MEFs generated by introducing immortalizing (GSE56) or transforming (GSE56 + Ras) genetic elements allowed us to classify them according to the stage of transformation that they represent (Table 1). We presumed that our genes of interest, those that act to prevent Ras-mediated transformation by causing premature senescence, are likely to be among genes that are either universally down- or upregulated in all immortalized and transformed cultures (universally p53-dependent) or after introduction of Ras (Ras- and p53-dependent).

Repression of gene expression is a predominant response to $p 53$ inactivation in MEFs

To investigate changes in gene expression resulting from inactivation of p53 and overexpression of oncogenic Ras that might account for acquisition of transformed phenotypes, we analyzed gene expression profiles of all of the above-described MEF populations using NIA 15K Mouse Developmental cDNA microarray, which contains 15,264 genes represented by 52,374 expressed sequence tags derived from pre- and peri-implantation embryos, embryonic day 12.5 female gonadymesonephros, and newborn ovary (Tanaka et al. 2000). Cy3-labeled cDNA probes were prepared from total RNA isolated from each MEF population, then mixed with control cDNA labeled with Cy5 (prepared from total RNA of original MEF) and hybridized with the array. Each RNA sample was analyzed twice (including synthesis of probes) to produce two independent replicas for comparative analysis of gene expression. Genes demonstrating a reliable twofold or greater difference in expression, as compared with control MEF in all comparative calculations inside and between the replicas, were picked for further analysis. A total of 1327 genes were found to be up- or down-regulated in all genetically modified populations analyzed, which represents $\sim 10 \%$ of the entire set of genes included in the array.

Importantly, clusterization of all transformed and immortalized MEF cultures according to the expression patterns of the 1327 selected genes revealed that they group exactly according to their biological properties (transformed and immortalized MEFs formed two separate clusters, while highly tumorigenic MEFs formed a separate subcluster distinct from weakly transformed MEFs) (Fig. 3A). This result allowed us to conclude that indeed we have obtained genetic "fingerprints" of individual stages of MEFs transformation. Since each transformation step was represented by several clonal populations, we could also define and eliminate from further analysis those genes that were specific for individual clones and, therefore, likely to reflect natural clonal variability of MEFs unrelated to the studied phenomenon. More than $70 \%$ of genes that passed through this selection criteria were found to be down-regulated in immortalized and transformed MEFs (Fig. 3A), indicating that gene repression was the predominant genetic response in MEFs that lack functional p53, independent of oncogenic Ras expression.

\section{Establishment of the list of tumor suppressor candidates}

After determining that phenotypically similar cell lines show clear hierarchical clustering, we have intersected their microarray profiles of down-regulated transcripts to obtain clone-independent sets of genes repressed in each phenotype (Fig. 3B). Our microarray analysis of immortalized and transformed phenotypes has revealed that inhibition of p53 results in the suppression of the genes

Table 1. Summary of the properties of genetically modified MEFs used for microarray profiling

\begin{tabular}{|c|c|c|}
\hline Cell line & Genotype & Phenotype \\
\hline $\begin{array}{l}56 \mathrm{R} 1 \\
56 \mathrm{R} 4\end{array}$ & WVild tum MFE & $\begin{array}{l}\text { Express high levels of RAS } 12 \text {, GSE56 and cyclin D1. Unlimited } \\
\text { growth at } 10 \% \text { and } 1 \% \text { serum. Growth in methyl cellulose } \\
\text { and athymic nu/nu mice. }\end{array}$ \\
\hline $\begin{array}{l}56 \mathrm{R} 2 \\
56 \mathrm{R} 7\end{array}$ & 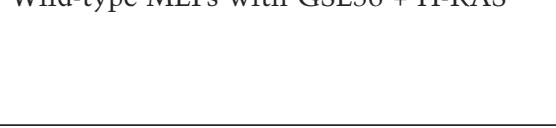 & $\begin{array}{l}\text { Express low levels of RAS }{ }^{\mathrm{v} 12} \text {, high levels of GSE56, no cyclin } \\
\text { D1 induction. Unlimited growth at } 10 \% \text { and } 1 \% \text { serum. } \\
\text { Weak or no growth in methyl cellulose and/or athymic mice. }\end{array}$ \\
\hline $\begin{array}{l}\text { 56SN1 } \\
56 \text { SN5 }\end{array}$ & Wild-type MEFs with GSE56 & $\begin{array}{l}\text { Express low to moderate levels of GSE } 56 \text {. Unlimited growth at } \\
10 \% \text { serum and arrest at } 1 \% \text {. No growth in methyl cellulose } \\
\text { and/or athymic mice. }\end{array}$ \\
\hline EGFP & Wild-type MEFs with EGFP & $\begin{array}{l}\text { Limited growth at } 10 \% \text { serum and arrest at } 1 \% \text {. No growth in } \\
\text { methyl cellulose and in athymic mice. }\end{array}$ \\
\hline
\end{tabular}


Boiko et al.

Figure 3. Microarray profiling of transformation mediated by suppression of p53 and overexpression of $\mathrm{H}-\mathrm{Ras}^{\mathrm{v} 12}$. (A) Hierarchical clustering of expression measurements from 1327 genes in MEFs with down-regulated p53 (56SN1, 56SN5) and in MEFs with down-regulated p53 that overexpress H-RAS ${ }^{\text {v12 }}$ (56R1, 56R2 56R4 56R7) and that show a consistent pattern of up- or down-regulation compared with primary MEFs. Each row represents a genetically modified MEF cell line and each column represents expression of a single gene across MEF specimens. Red indicates increased gene expression and blue indicates decreased gene expression relative to the median expression level in a primary MEF culture. The right panel shows the proportion of up- and down-regulated genes that exhibit the same pattern of regulation in hierarchically close MEF species. (B) Venn diagram of the number of genes whose suppression was common and unique between p53 dependent immortalization and transformation of MEFs. Down-regulated genes that exhibit the same pattern of regulation in hierarchically close transformed MEFs were intersected with downregulated genes from immortalized MEFs to identify the targets whose inhibition was mediated only by repression of p53, as opposed to the genes that required additional activity of oncogenic Ras in order to be repressed.

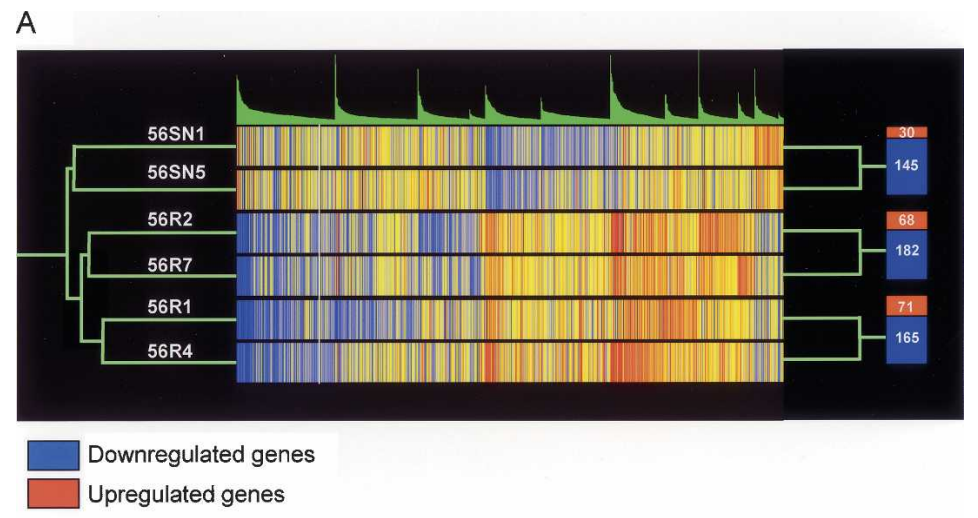

implicated in a wide variety of cellular processes. To distinguish which of those genes function as mediators of a p53-dependent tumor suppressive mechanism, we intersected clone-independent gene expression profiles of immortalized and transformed cells with inactivated p53 (Fig. 3B). Genes that were common for both profiles (Table 2 ) include potentially new tumor suppressor candidates that were repeatedly silenced in response to p53 inhibition when primary MEFs were induced to independently undergo immortalization or transformation. Not surprisingly, the list of genes presented in Gene Table 2 contains a number of known p53-responsive targets, such as Cyclin G1, BTG2, IGF-II, TGFß2, and PDGF . This set could contain genes, down-regulation of which determines the nature of cooperation of p53 suppression and oncogenic Ras in transformation of primary cells. In particular, 21 genes had been identified that exhibited clone-independent mode of regulation and were found to be down-regulated at all stages of transformation, including immortalized and partially transformed cells expressing GSE56 (Gene Table 2, in bold). In addition, 16 genes had been found that are not specific for partially transformed cells and might provide clues to the processes occurring at the later stages of epigenetic selection during transformation.

The second group of potential Ras cooperators is represented by the genes whose down-regulation was found

unique only to transformed phenotypes after comparative analysis of p53-mediated immortalization and transformation (Table 3). These genes are repressed as a result of oncogenic Ras expression in the absence of p53 and could include p53-independent targets that are either capable of cooperating with Ras during the course of transformation or directly and indirectly result from Ras signaling activity. Altogether, this list includes 62 genes that are repressed in all cell variants carrying oncogenic Ras (Table 3, in bold) and 29 genes that require high levels of Ras expression associated with complete transformation in order to be repressed. In addition, there are 27 unknown or uncharacterized EST sequences. The list of candidates contains several known genes directly related to Ras induced transformation such as H-Rev107 and Par-4 (Hajnal et al. 1994; Barradas et al. 1999).

We next sought to confirm the results of microarray analysis and picked three genes from each group of down-regulated genes to compare their expression in RNA samples isolated from transformed, immortalized, and primary cells. From the group of p53-dependent genes, we selected Cyclin G1, Gadd45y, and Hsp25; from the group of genes that responded to oncogenic Ras activity in addition to p53 inhibition, we selected $\mathrm{H}$ Rev107, Par-4, and eIF4G3. The results of hybridizations with genes selected from both groups were in complete accordance with microarray data and, more impor- 
Table 2. Genes repressed in a p53-dependent manner

\begin{tabular}{|c|c|c|}
\hline NIA 15K ID & Name & Symbol \\
\hline H3136H11-3 & Fibronectin leucine-rich transmembrane protein 2 & FLRT2 \\
\hline H3005D09-3 & Follistatin-like 3 & FSTL3 \\
\hline H3147В03-3 & Myosin regulatory light chain 2 smooth muscle isoform & MYRL2 \\
\hline H3126A04-3 & Insulin growth factor-II & IGF-II \\
\hline H3035В02-3 & Tropomyosin $\alpha^{\star}$ & TPM1 * \\
\hline H3135D11-3 & $\beta$-Tropomyosin isoform 2 & TPM2(2) \\
\hline H3054F05-3 & Lysozyme $M$ & LYZ \\
\hline H3002C07-3 & $\beta$-Tropomyosin isoform 1 & TPM2(1) \\
\hline H3059F09-3 & B-cell translocation gene $2^{\star}$ & BTG2* \\
\hline Н3053E04-3 & Calponin 1 & CNN1 \\
\hline H3054C02-3 & Growth arrest and DNA damage-inducible $\gamma 45^{\star}$ & GADD45 $\gamma^{\star}$ \\
\hline H3141F12-3 & Four and a half LIM domains 1 & FHL1 \\
\hline H3041F03-3 & Melanoma X-actin & ACTX \\
\hline H3009C10-3 & Serine protease inhibitor 6 & SPI6 \\
\hline H3082D09-3 & Small heat-shock protein $25^{\star}$ & HSP25 * \\
\hline H3055G07-3 & Transforming growth factor $\beta 2^{\star}$ & TGFß2* \\
\hline Н3109H11-3 & Cysteine-rich protein 2 & CRIP2 \\
\hline Н3024B07-3 & Cyclin $\mathrm{G}^{\star}$ & $\mathrm{CCNG} 1^{\star}$ \\
\hline H3037F12-3 & Dipeptidyl peptidase IV & DPP4 \\
\hline H3007H02-3 & Gap junction membrane channel protein $\beta 3$ & GJB3 \\
\hline H3125A09-3 & Glutathione peroxidase 3 & GPX3 \\
\hline H3016F06-3 & Nuclear myosin I $\beta$ & NM1 \\
\hline H3146C02-3 & Platelet derived growth factor $\alpha$ & PDGF $\alpha$ \\
\hline H3011A03-3 & Protein-L-isoaspartate D-aspartate O-methyltransferase 1 & PCMT1 \\
\hline H3042F12-3 & Serine protease inhibitor 4 & SPI4 \\
\hline H3137G02-3 & Glucocorticoid-inducible protein 5 & GIS5 \\
\hline
\end{tabular}

Table listing genes repressed in all of the cell lines expressing GSE56 in bold face type plus the genes whose down-regulation was unique only to highly tumorigenic cell lines. Genes marked with an asterisk were selected for further analysis.

tantly, support the overall pattern of gene repression obtained in silico for the rest of the genes delineated in immortalized and transformed cells (Fig. 4). The "p53only-dependent" group of genes show little dependency for hyperactive Ras in order to decrease their expression to the level that permits primary cells to undergo transformation (Fig. 4A,B). By contrast, genes whose inhibition requires activity of oncogenic Ras in the absence of p53 demonstrate a different pattern of suppression. Abolishment of functional p53 by GSE56 has very minimal effect on the expression of these genes as seen from Northern blot analysis of $H$-Rev107 and Par-4 (Fig. 4C,D) and might serve only as an initiation step toward their silencing (Fig. 4C, cf. EGFP and GSE56), a process that in this case drastically depends on the activity of mutant Ras.

The identification of known p53-responsive and oncogenic Ras-regulated genes in our experimental setup and the confirmation of their down-regulation pattern by Northern analysis provided strong supportive evidence that our list of selected candidate tumor suppressors indeed contains biologically relevant genes.

Screening of gene-specific shRNAs in Ras cooperation assay reveals BTG2 as a repressor of Ras-mediated transformation

Identification of gene repression as a predominant pattern of global transcriptional changes in MEFs undergo- ing transformation, as well as candidate gene targets themselves, have provided a basis for a screening design aimed at the isolation of new tumor suppressor genes. This approach was based on the combination of RNA interference (RNAi)-mediated gene silencing technology (Mello and Conte 2004) together with a Ras cooperation screening assay to identify the genes whose suppression would promote transformation of primary cells.

Our hypothesis was that genes acting as mediators of p53 tumor-suppressive function were likely to be among those that were universally down-regulated in all transformed and immortalized cultures that express GSE56. From genes delineated in Table 2, we selected six candidates (encoding TPM1, BTG2, GADD45 $\gamma$, HSP25, TGF 2 2, and CCNG1) with most relevant biological function for testing whether their down-regulation would promote Ras-mediated transformation of primary cells. Nonetheless, we could not completely exclude those genes that, in addition to p53 inactivation, required $\mathrm{H}-\mathrm{Ras}^{\mathrm{v} 12}$ signaling to be repressed and mediate induction of the neoplastic phenotype. Thus, we included a subset of transcripts from Table 3 (PAR-4, DOK-1, H-Rev107, eIF4G3) to the previously selected group of genes. Short inverted repeats homologous to the identical regions of mouse and human genes selected from Tables 2 and 3 and picked with the aide of PickSi software were synthesized and cloned into retroviral pLHXPS vector under the control of an $\mathrm{H} 1$ promoter, thus allowing RNA polymerase III-driven expression of 
Boiko et al.

Table 3. Genes repressed in a p53+HRas ${ }^{\mathrm{V} 12}$-dependent manner

\begin{tabular}{|c|c|c|}
\hline NIA 15K ID & Name & Symbol \\
\hline Н3011B01-3 & Mitogen inducible gene & MIG-2 \\
\hline Н3114H08-3 & 37 Kda leucine-rich repeat LRR protein & p37NB \\
\hline H3125D01-3 & Collagen type I $\alpha 2$ & COL1 $1 \alpha 2$ \\
\hline Н3085H02-3 & Protein disulfide isomerase-related & PDIR \\
\hline H3116А08-3 & General transcription factor $3 \mathrm{C}$ polypeptide 2 & GTF3C2 \\
\hline H3115C09-3 & Lim domain-containing translocation partner in lipoma & LPP \\
\hline H3136G08-3 & Caldesmon 3' UTR & CALD1 \\
\hline H3152F10-3 & Pmepa1 protein & PMEPA1 \\
\hline Н3038E03-3 & PRKC apoptosis WT1 regulator ${ }^{\star}$ & $\mathbf{P A W R}^{\star}$ \\
\hline Н3059В02-3 & Regulator of G-protein signaling 12 & RGS12 \\
\hline H3038D07-3 & Similar to kinesin-like 4 & KNSL4 \\
\hline H3152G04-3 & $\alpha-2$ collagen type VI subunit & $\operatorname{COL} 4 \alpha-2$ \\
\hline H3098G04-3 & Red-1 gene & MXN \\
\hline Н3124В09-3 & Amyloid $\beta$ precursor protease & APP \\
\hline H3018F05-3 & P-cadherin 3 & CDH3 \\
\hline H3026G09-3 & Pro- $\alpha 1$ II collagen chain gene & $\operatorname{COL} 2 \alpha-1$ \\
\hline H3052F12-3 & Spi2 proteinase inhibitor & SPI2/EB1 \\
\hline H3137C06-3 & Transglutaminase & TGASE \\
\hline H3159G06-3 & $\alpha-1$ type IV collagen & $\operatorname{COL} 4 \alpha-1$ \\
\hline H3140F04-3 & Annexiin A6 & ANXA6 \\
\hline Н3009В01-3 & Bone morphogenic protein & BMP-1 \\
\hline Н3039Н01-3 & Calponin 2 & CNN2 \\
\hline H3015E11-3 & C-terminal Lim domain protein 1 & PDLIM1 \\
\hline Н3090F04-3 & Chondroitin 4-O-sulfotransferase & C4ST-2 \\
\hline H3057D05-3 & Colony-stimulating factor 1 macrophage & CSF1 \\
\hline Н3005E03-3 & Cysteine-rich protein & CSRP \\
\hline H3053А08-3 & Cytochrome P450 & CYP1A1 \\
\hline H3124Е04-3 & CXC chemokine ligand 12 & CXCL12 \\
\hline H3124A07-3 & elF4E-like protein ${ }^{\star}$ & $4 \mathrm{E}-\mathrm{LP}{ }^{\star}$ \\
\hline Н3120B11-3 & Fibulin 2 & FBLN2 \\
\hline H3046А09-3 & Fk506-binding protein 6 & FKBP6 \\
\hline Н3119Н03-3 & Fvb/N collagen pro- $\alpha-1$ type I chain & $\operatorname{COL} 1 \alpha-1$ \\
\hline H3154E07-3 & Growth-arrest-specific 6 & GAS6 \\
\hline H3066G03-3 & Guanine nucleotide-binding protein $\alpha 14$ & GNA14 \\
\hline H3126F05-3 & Insulin-like grwoth factor-binding protein 5 & IGFBP5 \\
\hline Н3031Н04-3 & Integrin $\beta-5$ & ITG $\beta 5$ \\
\hline H3122E01-3 & Leman coiled-coil protein variant 1 & LCCP \\
\hline H3150Е06-3 & Lymphocyte-specific 1 & LSP1 \\
\hline Н3040F11-3 & Lysosomal thiol reductase & IFI30 \\
\hline H3136G09-3 & Luman basic leucine zipper protein & LZIP \\
\hline H3058D07-3 & Matrix metalloproteinase 23 & MMP23 \\
\hline H3146E06-3 & S-Gicerin/Muc18 & MCAM \\
\hline H3122G06-3 & Neuropilin & NRP \\
\hline H3038G07-3 & Nuclear receptor corepressor 2 & NCOR2 \\
\hline H3134H12-3 & Osteoblast-specific factor 2 fasciclin I-like & OSF2 \\
\hline Н3122Н01-3 & Paxillin-like protein gene & HIC5 \\
\hline Н3028H10-3 & Peptidylprolyl isomerase C & PPIC \\
\hline H3140C02-3 & Platelet-derived growth factor receptor $\beta$ & PDGFR $\beta$ \\
\hline H3156E09-3 & Procollagen type $V \propto 2$ & $\operatorname{COL} 5 \alpha 2$ \\
\hline H3017E11-3 & Retinoblastoma-binding protein 7 & RBBP7 \\
\hline Н3001H12-3 & Ribosomal protein S6 kinase 90kd polypeptide 2 & RPS6KA2 \\
\hline H3002E01-3 & Selenoprotein $\mathbf{R}$ & SEPR \\
\hline H3031C08-3 & Sh3 domain protein 5 & SH3D5 \\
\hline Н3115E04-3 & Shroom & SHRM \\
\hline H3119А03-3 & Synapsin I & SYN1 \\
\hline Н3109С02-3 & Tissue inhibitor of metalloproteinase 3 & TIMP3 \\
\hline H3116G07-3 & Transmembrane 4 superfamily member 6 & TM4SF6 \\
\hline H3159E09-3 & Unc-51-like kinase 2 C. elegans & ULK2 \\
\hline H3008А09-3 & Ras homolog gene family, member B & RhoB \\
\hline Н3040H07-3 & Hras-revertant gene $107^{\star}$ & HREV107* \\
\hline Н3101H02-3 & Mytonic dystrophy kinase-related Cdc42-binding kinase & MRCK \\
\hline H3129C10-3 & Steroid-sensitive gene-1 & SSG-1 \\
\hline
\end{tabular}


Table 3. (continued)

\begin{tabular}{|c|c|c|}
\hline NIA 15K ID & Name & Symbol \\
\hline H3055G12-3 & Thrombin receptor & CF2R \\
\hline Н3123А05-3 & Staufen RNA-binding protein homolog 1 & STAU1 \\
\hline H3153А05-3 & Socs box-containing Wd protein & SWIP-2 \\
\hline H3113F12-3 & Short incubation prion protein & PRNPA \\
\hline H3061D06-3 & Fat 1 cadherin & MFAT1 \\
\hline H3151E12-3 & Downstream of tyrosine kinase $1^{\star}$ & $\mathrm{DOK} 1^{\star}$ \\
\hline H3115F11-3 & Nidogen 2 & NID2 \\
\hline H3020G05-3 & Nebulin-related anchoring protein & NRAP \\
\hline H3010D09-3 & Vinculin & VCL \\
\hline H3104D07-3 & Mammary-derived growth inhibitor & MDGI \\
\hline Н3120B07-3 & Gelsolin & GSN \\
\hline H3121C02-3 & Follistatin-like protein & FSTL \\
\hline H3110F10-3 & Epoxide hydrolase 1 & EPHX1 \\
\hline H3056G12-3 & Enigma homolog 2 & ENH2 \\
\hline H3152D01-3 & Cyclin D2 & CCND2 \\
\hline H3116С03-3 & Subcomponent C polypeptide & $\mathrm{C} 1 \mathrm{QC}$ \\
\hline H3121G09-3 & Chondroitin sulfate proteoglycan 2 & CSPG2 \\
\hline Н3097В09-3 & Cd97 antigen & CD97 \\
\hline H3079D07-3 & Coiled-coil protein 1 & $\mathrm{CC} 1$ \\
\hline H3081D02-3 & Bcl-2-related ovarian killer & BOKL \\
\hline H3125C05-3 & Prolyl 4-hydroxylase & $\mathrm{P} 4 \mathrm{HB}$ \\
\hline H3114H12-3 & Collagen $3 \alpha-1$ & $\operatorname{COL} 3 \alpha 1$ \\
\hline H3134D09-3 & Semaphorin III family homolog & SEMA3 \\
\hline Н3019H02-3 & Vanilloid receptor 1 & VR1 \\
\hline H3075F12-3 & Tumor endothelial marker 8 & TEM 8 \\
\hline Н3053А07-3 & Spinocerebellar ataxia 1 & SCA1 \\
\hline H3116A11-3 & Px19-like protein & PX19 \\
\hline Н3017Н10-3 & Lim and Sh3 protein 1 & LASP1 \\
\hline H3116Е09-3 & Core histone macroh $2 \mathrm{a} 2.2$ & MACROH2A2 \\
\hline
\end{tabular}

Table listing genes repressed in all of the cell lines expressing GSE56 + HRas ${ }^{\mathrm{v12}}$ in bold plus the genes whose downregulation was unique only to highly tumorigenic cell lines. Genes marked with an asterisk were selected for further analysis.

shRNAs against the genes of choice. As a control, mouse p53 cDNA was also included in the list of target genes to monitor the efficiency of inhibitory oligo sequence selection as well as their ability to mediate Ras transformation in functional assays that followed the synthesis and cloning of shRNAs.

Primary MEF cultures were infected first with shRNAexpressing retroviruses targeting gene candidates, either individually or as a mixture. Seventy-two hours later, each cell population was infected with retroviral constructs expressing H-Ras ${ }^{\mathrm{v} 12}$ in combination with neomycin resistance gene followed by G418 selection to eliminate cells that were not transduced with oncogenic Ras. After $14 \mathrm{~d}$ of selection, cells infected with control shRNA (targeting GFP) failed to grow, forming a culture of sparse growth-arrested cells displaying characteristics of a senescent phenotype, while cells transduced with a mixture of shRNAs as well as with individual shRNAs against p53 and one of the candidate genes, BTG2, produced numerous colonies of proliferating cells with grossly transformed morphology (Fig. 5A). The inhibitory effect of shRNAs on the expression of target genes was confirmed by measuring the level of their corresponding mRNAs using semiquantitative RT-PCR or real-time RT-PCR assays (shown for BTG2 and p53 in Fig. 5B,C).
BTG2 was previously isolated as an early growth-response gene (Bradbury et al. 1991) whose expression can be modulated by p53 when induced by DNA-damaging agents (Rouault et al. 1996). Here, for the first time, we show that down-regulation of BTG2, similarly to p53, makes cells susceptible to oncogenic transformation.

To further investigate the tumorigenic properties of the cells transformed with BTG2 shRNA and activated Ras, we have analyzed their anchorage dependence and tumorigenicity. When plated in semisolid media containing methylcellulose, these cells, in sharp contrast to those transduced with shRNA against GFP and H-RAS ${ }^{v 12}$, were able to grow and formed numerous colonies (Fig. 5D). For in vivo tumorigenicity assays, $10^{7}$ cells of each cell type were injected subcutaneously in both flanks of four female nu/nu or SCID/Beige mice. After 14 $\mathrm{d}$, cells transformed with BTG2 shRNA and mutant Ras formed tumors at all sites of injection, indicating that they have acquired complete neoplastic phenotype (Fig. 5E).

We next sought to determine whether p53 modulates expression of BTG2 during immortalization and transformation of the primary cells. Real-time PCR analysis of MEFs expressing GSE56 with or without oncogenic Ras revealed that functional inactivation of p53 is always accompanied by the significant reduction in BTG2 
A

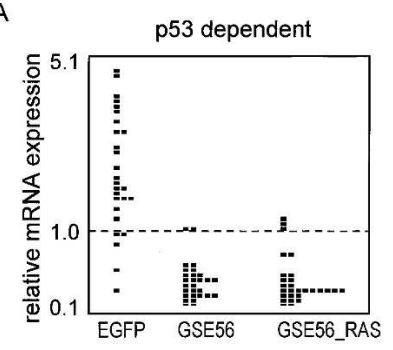

B

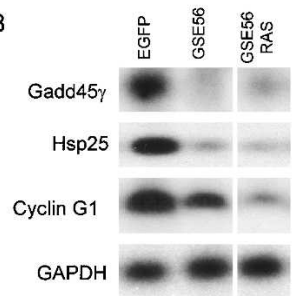

C

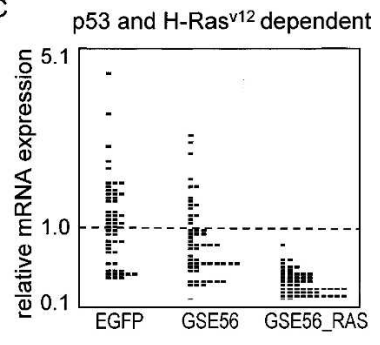

D

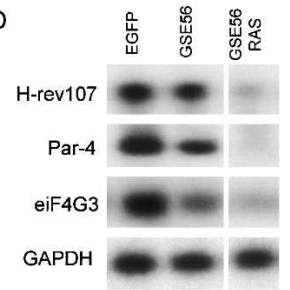

Figure 4. Comparison of behavior of the genes that become repressed after p53 knockdown in the presence or absence of oncogenic Ras among three types of cell cultures. $(A)$ Relative expression of the genes that were commonly down-regulated in both immortalized and transformed cells. Values of expression are calculated relative to average gene expression level (dotted line) determined for all genes represented in the array. $(B)$ Northern blot analysis of indicated genes that were down-regulated in MEFs in response to p53 suppression and independent of oncogenic Ras overexpression. (C) Relative expression of the genes that were down-regulated exclusively in transformed cells. Values of expression are calculated relative to average gene expression level (dotted line) determined for all genes represented in the array. $(D)$ Northern blot analysis of indicated genes whose down-regulation was only specific for transformed MEFs where p53 inhibition was accompanied by overexpression of $\mathrm{H}-\mathrm{Ras}^{\mathrm{v} 12}$.

expression (Fig. 5F). Similar to GSE56, cells expressing shRNA targeting p53 had reduced the level of BTG2 mRNA (Fig. 5B). Cells transduced with shRNA against BTG2 retain p53 mRNA levels unchanged (Fig. 5C); moreover, p53 in BTG2-knockdown cells was functional as judged by the activation of $\mathrm{p} 53$ reporter construct, pWafConA_mCMVLacZ, in response to p53-inducing stimuli (Fig. 5G). We then analyzed expression of p21, one of the main p53-dependent target genes that mediate growth arrest function of p53 upon DNA damage (elDeiry et al. 1993). shRNA-mediated knockdown of BTG2 did not affect p53-mediated induction of p21 by oncogenic Ras (Fig. 5H). Since functional inactivation of p53 in MEF can be reached by the loss of $A R F$ expression (Inoue et al. 2000; Kamijo et al. 1997), we analyzed the expression of this gene in shBTG2 + Ras-transformed MEF. ARF expression was detectable in all MEF cell populations, including those expressing shRNA against $B T G 2$, and its expression became elevated after transduction of oncogenic Ras (Fig. 5J), thus showing the expected pattern of regulation (Palmero et al. 1998; Lin and Lowe 2001).

Our data, therefore, demonstrates that suppression of p53 target gene, BTG2, can indeed sensitize cells to the

acquisition of tumorigenic phenotype in the presence of functional p53, thus providing a missing link between p53 activation and growth suppression.

\section{Suppression of BTG2 overcomes Ras-induced growth} arrest of human fibroblasts

Since our experiments with mouse cells demonstrated that inhibition of BTG2 can mimic suppression of p53 in its ability to rescue Ras-mediated senescence, our next step was to test whether BTG2 suppression could play a similar role in human cells.

Similar to mouse cells, activation of oncogenic Ras in human fibroblasts induces terminal growth arrest phenotypically similar to cellular senescence (Serrano et al. 1997; Lin et al. 1998). However, in human cells, induction of senescence in response to oncogenes depends on the integrity of p53 and p16/pRb pathways. In some reports, $\mathrm{p} 16 / \mathrm{pRb}$ function was shown to be a major factor preventing senescence-associated growth arrest in human fibroblasts transduced by oncogenic Ras (Serrano et al. 1997; Wei et al. 2001), while others suggest that p53 is of equal importance (Voorhoeve and Agami 2003). Apparent controversy between these reports most likely is due to the fact that the levels of p16 vary significantly among substrains of human fibroblasts and their passaging history in cell culture.

We transduced early-passage human diploid fibroblasts IMR90 having low basal expression levels of p16 (data not shown) with lentiviral vectors expressing inhibitory shRNAs against human BTG2, p53 (Brummelkamp et al. 2002), or GFP, followed by infection with another lentiviral vector coexpressing $\mathrm{H}$-Ras ${ }^{\mathrm{V} 12}$ and neomycin resistance genes. After 2 wk of G418 selection, it became evident that introduction of shRNA against BTG2 or p53 rescued IMR90 cells from growth arrest caused by transduction of oncogenic Ras (Fig. 6A). While $\sim 95 \%$ of IMR90 cells transduced by control shRNA against GFP and Ras stained positive for a senescence marker (acidic $\beta$-galactosidase) and stopped growing, only $30 \%$ of cells expressing shRNAs against BTG2 and $5 \%$ of cells expressing shRNA against p53 showed positive $\beta$-galactosidase staining and these cultures were able to proliferate, regardless of the presence of oncogenic Ras, until they reached confluence (Fig. 6B). Further passaging of these cells indicated that they indeed escaped (rather than delayed) Ras-mediated growth arrest. The efficacy of inhibitory effect of previously isolated mouse shRNA for human gene homolog of BTG2 was confirmed using real-time RT-PCR (Fig. 6C). Thus, similar to mouse cells, inhibition of BTG2 allows human fibroblasts to overcome the growth suppressive effect of Ras oncoprotein.

Knockdown of BTG2 results in up-regulation of cyclins $D 1$ and $E 1$ and phosphorylation of $R b$ and contributes to transformation of human fibroblasts

Loss of protective response against oncogenic stress is an essential step toward neoplastic transformation. There- 
A

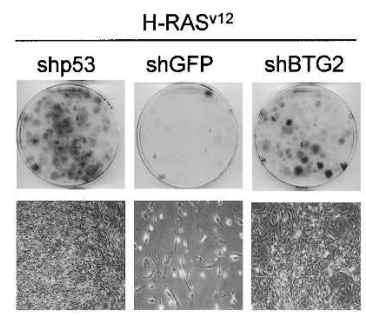

$\mathrm{B}$

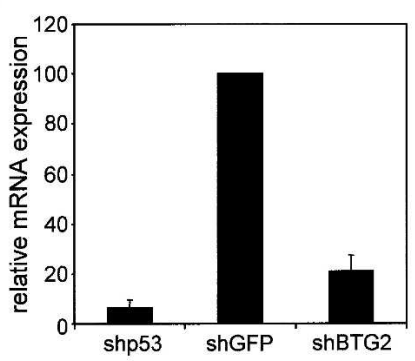

C

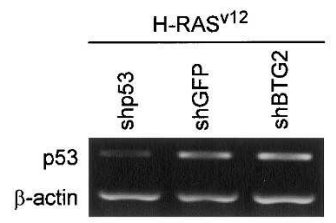

D

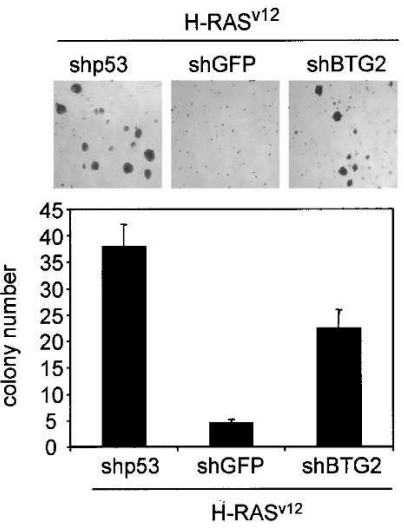

E

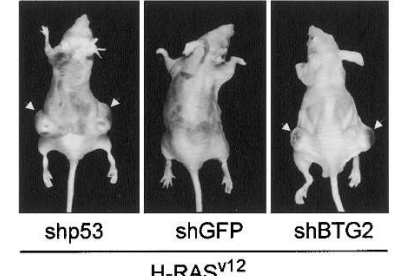

$\mathbf{F}$

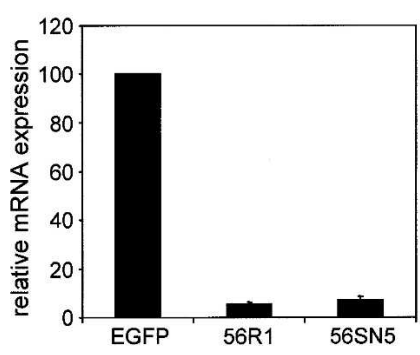

G

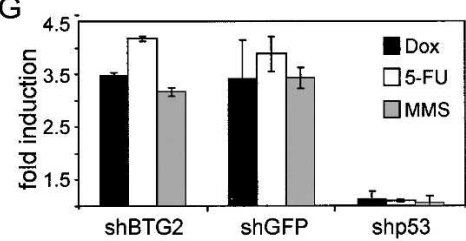

$\mathrm{H}$

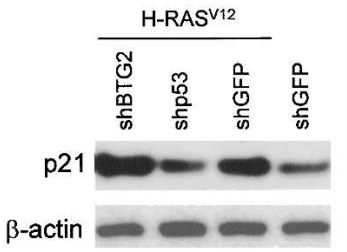

$J$

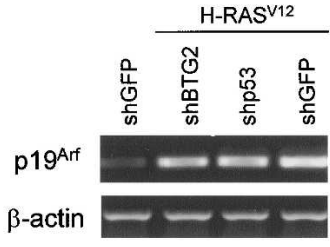

Figure 5. shRNA-mediated knockdown of BTG2 or p53 allows Ras-mediated transformation of primary MEFs. (A) Primary MEFs were infected with a mixture as well as with individual shRNAs against candidate tumor suppressor genes; all cultures were then superinfected with LRasSN virus-containing supernatants and then seeded at $5 \times 10^{5}$ cells per $100-\mathrm{mm}$ plate. Infected populations were grown in the presence of $0.4 \mathrm{mg} / \mathrm{mL}$ of G418. Morphologically transformed colonies appearing 2 wk later were photographed, stained, and counted. $(B)$ Real-time PCR analysis of BTG2 mRNA levels in cells expressing shRNAs for BTG2, p53, and GFP. (C) Semi-quantitative RT-PCR analysis of p53 mRNA levels in cells expressing shRNA for p53, BTG2, and GFP. (D) MEFs transformed by a combination of oncogenic Ras and shRNAs for the indicated genes were resuspended in normal culture medium containing $1.4 \%$ methyl cellulose and seeded at $10^{4}$ cells per well, and in duplicates into six-well plates coated with $1.2 \%$ low-melting-point agarose. Cultures were grown under standard tissue culture conditions, cells were fed twice weekly, and the number of macroscopically visible foci was scored after $3 \mathrm{wk}$. $(E)$ The ability to form tumors in vivo was assessed by injecting $4 \times 10^{6}$ transformed cells under the skin of both flanks of athymic nu/nu mice; growth of tumors was analyzed 18 d later. $(F)$ Levels of BTG2 mRNA in MEFs expressing GSE56 + HRas, GSE56, or EGFP used for microarray analysis determined by real-time PCR. (G) p53 retains its transactivation ability in the cell with down-regulated BTG2 (results of detection of the activity of p53-responsive lacZ after induction with the indicated DNA-damaging drugs). (H) Western blot analysis of p21 expression in MEFs transduced with constructs expressing shRNAs against the indicated genes with or without oncogenic H-RAS ${ }^{\mathrm{v} 2} \cdot \beta$-Actin is used as loading control. (J) Semiquantitative RT-PCR analysis of ARF mRNA levels in MEFs expressing shRNA against p53, BTG2 and GFP, with or without oncogenic H-RAS ${ }^{\text {v12 }}$.

fore, we next examined whether suppression of BTG2 can promote and be part of a multistep transformation process in human cells. With identification of a minimal set of genetic elements sufficient for neoplastic transformation of human primary cells (Hahn et al. 1999, 2002; Voorhoeve and Agami 2003), it has become possible to address the individual role of candidate tumor suppressor genes in human oncogenesis. We transduced IMR90 cells with lentiviruses expressing catalytic subunit of human telomerase (H-TERT), small t-antigen of SV40 (st), and oncogenic Ras (IMR90-TtR). Expression of all these proteins is essential, but not sufficient, for full transformation of human fibroblasts, which also requires inactivation of both p53 and pRb pathways (Hahn et al. 2002; Voorhoeve and Agami 2003; Rangarajan et al. 2004).

Since BTG2 was functioning as a downstream member of the p53 pathway in mouse cells, we expected that repression of this gene might substitute inhibition of p53 and, in cooperation with $\mathrm{pRb}$ repression, lead to full transformation of human cells. To test this assumption, we delivered shRNA against BTG2, with or without shRNA against p16 (Voorhoeve and Agami 2003), to IMR90-TtR cells. shRNA against p53 and GFP were used as positive and negative controls, respectively. Surprisingly, suppression of BTG2 did not induce anchorageindependent growth of IMR90-TtR cells even if introduced in combination with shRNA against $p 16$ (data not shown). At the same time, shRNA against BTG2 dramatically induced anchorage independent growth of IMR90-TtR cells if combined with p53 inhibitory element GSE56 (Fig. 7A). This effect of shRNA against $B T G 2$ was similar to that of shRNA against $p 16$, suggesting that BTG2 is involved in regulation of $\mathrm{Rb}$ pathway and therefore suppression of BTG2 can cooperate with suppression of p53 in transformation of human fibro- 
Boiko et al.

blasts. Recent reports indicate that BTG2 can be induced by $\mathrm{p} 53$-independent mechanisms including NF-кB activation and ARF signaling (Kuo et al. 2003; Kawakubo et al. 2004) that might explain why additional down-regulation of BTG 2 is required, even when p53 is repressed, in order to reach transformed phenotype.

To gain insights in the mechanisms of cooperation between down-regulation of BTG2 and p53 in transformation of IMR90-TtR fibroblasts, we analyzed expression of various cell cycle regulatory proteins known to be deregulated by oncogenic Ras and involved in the establishment of neoplastic phenotype. Western blot analysis data indicate that expression of shRNA against BTG2 in IMR90-TtR cells with GSE56 results in the up-regulation of cyclins D1 and E1 (Fig. 7B) as compared with the nontransformed IMR90-TtR-GSE56 cells. Thus, for the

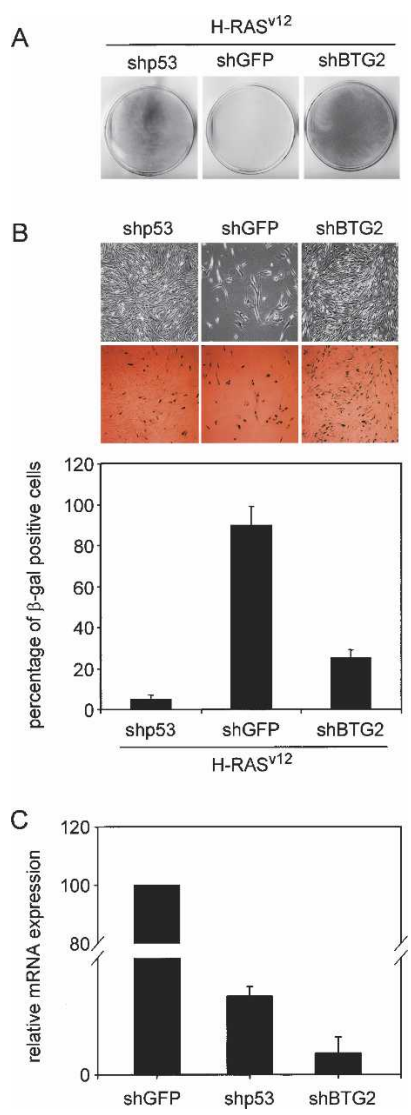

Figure 6. Inhibition of BTG2 rescues human diploid embryonic lung fibroblasts, IMR90, from oncogene-mediated growth arrest. (A) IMR-90 cells infected with shRNAs against BTG2, p53, and GFP were superinfected with lentivirus-expressing $\mathrm{H}-\mathrm{Ras}^{\mathrm{v} 12}+\mathrm{NeO}^{\mathrm{r}}$ cassette and selected in G418-containing media for $14 \mathrm{~d}$, after which surviving resistant cells were fixed and stained with Methylene Blue. (B) Resistant IMR-90 cells expressing $\mathrm{H}-\mathrm{Ras}^{\mathrm{v} 12}+\mathrm{NeO}^{\mathrm{r}}$ and shRNAs for the indicated genes were stained for senescence-associated endogenous $\beta$-galactosidase activity and photographed. Results were calculated as the percentage of visible cells that had positive staining (at least five different fields were counted for each plate). (C) BTG2 expression is down-regulated in IMR-90 cells that express shRNA for BTG2 or p53 as measured by real-time PCR.

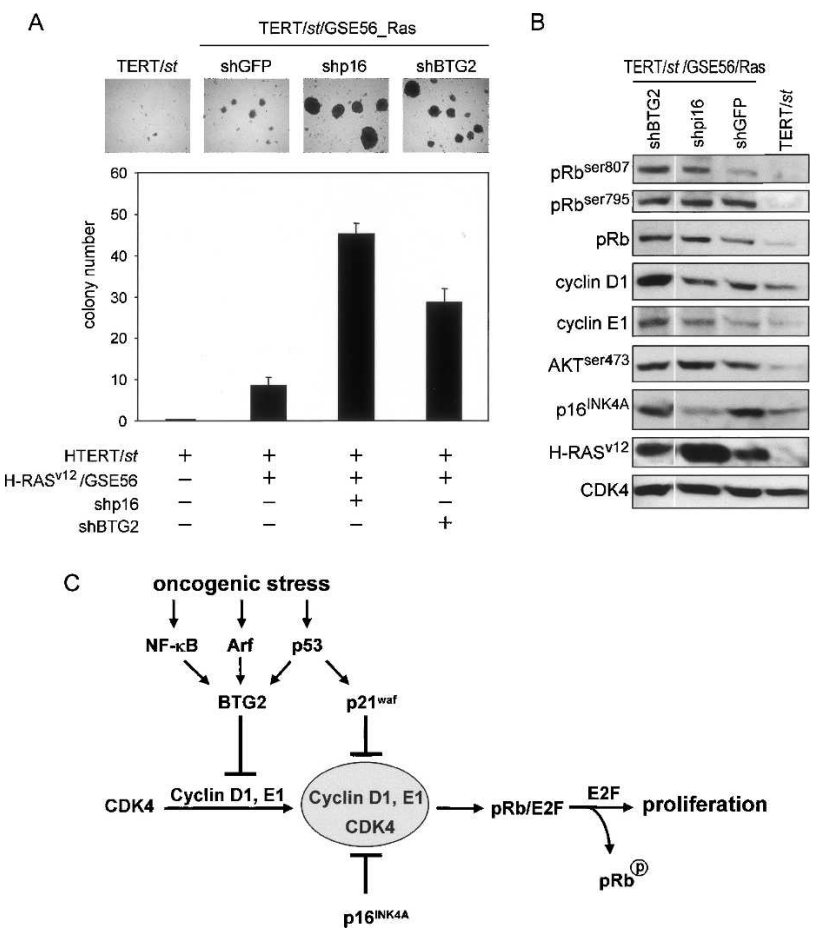

Figure 7. BTG2 cooperates with p53 to prevent transformation of human IMR90 cells. (A) Primary IMR90 cells were sequentially infected to express a combination of oncogenic elements that are required but not sufficient for tumorigenic transformation (TERT/st/GSE56/Ras), and then super infected with shRNA lentiviral constructs against the indicated genes. Cells were grown in methyl cellulose and the number of macroscopically visible foci was scored after $3 \mathrm{wk}$. $(B)$ Western blot analysis of genetically transduced IMR90 cells for the expression of the indicated proteins. $(C)$ A model in which BTG2 integrates p53 and other signaling networks to control cell division. Cell proliferation and, ultimately, formation of malignant tumors largely depends on pRb phosphorylation status, which controls the activity of the E2F family of transcription factors necessary for induction of the genes that regulate DNA synthesis. $\mathrm{Rb}$ phosphorylation status is, in turn, mediated by CDKs bound to activating cyclins. Oncogenic and other stress signals that might lead to the formation of a malignant phenotype activate BTG2 through p53-dependent and p53-independent mechanisms leading to reduced expression of D- and E-type cyclins, hypophosphorylation of $\mathrm{Rb}$, and the inhibition of cell growth.

first time up-regulation of G1-type cyclins has been directly linked to BTG2 down-regulation in human cells. Previous reports on the down-regulation of cyclin D1 mRNA level in 3T3 cells (Guardavaccaro et al. 2000) or cyclin E1 in 293T cells (Lim et al. 1998) which ectopically overexpessed BTG2, complement our data. Cyclins $\mathrm{D} 1$ and E1 are key regulators of CDK4, CDK6, and CDK2, which are activated upon binding to corresponding cyclins (Koff et al. 1991; Matsushime et al. 1992; Xiong et al. 1992; Meyerson and Harlow 1994) after their induction by growth-activating signals (Won et al. 1992; Ohtani et al. 1995). We further analyzed whether upregulation of cyclins D1 and E1 by shRNA against BTG2 affected the phosphorylation status of $\mathrm{Rb}$, the main tar- 
get of CDK4/Cyclin D1 and CDK2/Cyclin E1 complexes, which controls G1/S entry checkpoint and is one of the most critical factors affecting cellular decision between proliferation and growth arrest or apoptosis (Sherr 1993; Weinberg 1995). While the protein level of $\mathrm{Rb}$ was not largely affected by the BTG2 suppression, phosphorylation of Ser807 but not Ser795 was strongly induced in the cells expressing shRNA against BTG2 (Fig. 7B).

Part of the biological effects of Ras are mediated via Akt pathway (Khwaja et al. 1997) which can result in modulation of cyclin D1 expression both at protein and mRNA levels (Diehl et al. 1998; Burgering and Medema 2003). Hence, we tested whether the effect of BTG2 suppression on the expression cyclin D1 could be due to the differences of Akt activation. As shown in Figure 7B, oncogenic Ras induces phosphorylation of Akt at Ser473, however, none of the above described genetic modifications, including expression of shRNAs against BTG2 or p16 had any effect on the protein level of activated Akt.

Based on these results, we propose a model (Fig. $7 \mathrm{C}$ ) in which BTG2 is a critical point of convergence of signaling pathways, including p53, that regulates phosphorylation of $\mathrm{Rb}$ through the expression of $\mathrm{D}$ - and E-type cyclins, which is necessary to inactivate $\mathrm{Rb}$-mediated block of proliferation and turn on E2F-dependent promoters required for cell cycle progression and survival (Dyson 1998; Harbour et al. 1999; Ezhevsky et al. 2001).

\section{Down-regulation of BTG2 in human cancers}

The BTG2 gene localizes to chromosomal locus 1q32 (Rouault et al. 1996), which is frequently lost in a subset of breast cancers (Chen et al. 1989). Immunohistological studies have shown that BTG2 is highly expressed in several normal tissues, including kidney proximal tubules, lung alveolar bronchial epithelia, and prostate acinar cells (Melamed et al. 2002) and reduced BTG2 expression was recently reported in various cancer cell and malignant tissue samples (Ficazzola et al. 2001; Kawakubo et al. 2004; Struckmann et al. 2004). After establishing the link between BTG2 suppression and transformation in both mouse and human cell lines, we wished to determine whether deregulation of this gene has any clinical relevance. To test how common the changes in BTG2 expression in human tumors are, we used the BD Clontech Cancer Profiling Array I, which contains multiple pairs of cDNA samples generated from mRNAs of matched tumor and normal tissue samples of the same patient. Overall, this array includes 13 tissues, most of which are represented by 10 or more patients. Nylon membranes containing cDNA samples normalized to the housekeeping genes, $\beta$-actin and ubiquitin, were hybridized with the ${ }^{32}$ P-labeled BTG2 cDNA probe. Relative intensities of the signals, reflecting relative abundance of BTG2 mRNA in normal versus tumor tissues, were quantitated and the results were plotted using logarithmic scale. After analysis of obtained results we found that expression of BTG2 was down-regulated in a large proportion of renal and breast cell carcinomas and to lesser extent in patients with stomach cancer (Fig. 8),

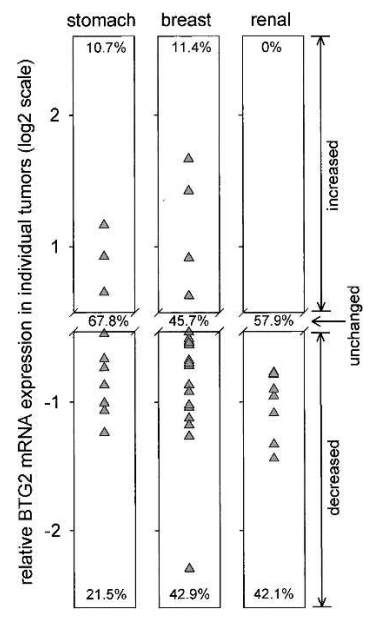

Figure 8. BTG2 expression analysis in human cancers using BD Clontech Cancer Profiling Array I, consisting of genetically matched cDNA pairs derived from tumor and adjacent normal tissue samples.

thus arguing for the importance of BTG2 down-regulation in naturally occurring human cancer.

\section{Discussion}

p53 is one of the most frequently mutated genes found in human cancers (Levine 1997). Inactivation of p53 makes cells susceptible to transformation by activated oncogenes in vitro and makes both mice and humans (LiFraumeni syndrome patients) highly cancer prone (Finlay et al. 1989; Donehower et al. 1992; Malkin 1994). Consistently, wild-type p53 can inhibit tumor cell growth in vitro and in vivo and makes primary cells resistant to oncogenic transformation (Eliyahu et al. 1989; Baker et al. 1990). The mechanisms of p53 activation by dominant oncogenes, including oncogenic Ras, are relatively well understood and involve transcriptional activation of tumor suppressor ARF detracting Mdm2 from p53 (Kamijo et al. 1997; Jacobs et al. 1999; Inoue et al. 2000). In contrast, factors acting downstream of p53 and capable of inhibiting cell growth in response to oncogenic signaling remain largely unknown. Although there is a strong belief that p53 exerts its tumor suppressor function through transcriptional regulation, it remained unclear which, among the wealth of p53-responsive genes identified, are responsible for Ras-induced growth arrest.

In this work we developed an approach to identification of such genes. It involved gene expression profiling of different stages of transformation of mouse fibroblasts by the combination of p53-suppressing element and oncogenic Ras followed by the establishment of the list of candidate suppressors of Ras-mediated transformation and their functional validation via screening of focused shRNA in Ras transformation assays. Although microarray-based gene expression profiling of p53-dependent transcription has been applied previously to several cell 
systems (Polyak et al. 1997; Kannan et al. 2000; Zhao et al. 2000), we for the first time compared p53-dependent changes in gene expression between normal nontransformed MEFs and MEFs that underwent a single-step transformation. In fact, the most common models used in the studies of Ras-induced transformation involve immortalized cells (such as NIH 3T3), which are suitable for transformation by a single oncogene. Hence, such cells have presumably already acquired genetic alterations, including reduced expression of tumor suppressor genes, which prevent primary MEF from transformation. Indeed, loss of p53 function seems to be a prerequisite for transformation, but the genes through which it exerts its growth arrest activity in response to Ras remained unknown, although they are likely to be found among the p53-responsive ones. To avoid analysis of established immortalized cell cultures that have passed through numerous generations in vitro and could acquire genetic alterations irrelevant to predisposition to transformation, we have designed a retroviral construct coexpressing GSE56, and H-Ras ${ }^{\mathrm{v} 12}$, which was capable of full single-step transformation of primary cells. The use of GSE56-only retrovirus allowed us to distinguish between p53- and Ras-dependent effects and to pick those genes that were stably deregulated by p53 suppression alone and in combination with Ras. Another technically important solution that allowed us to dramatically reduce the number of candidates for testing was parallel analysis of several independently picked clonal cell populations, which made it possible to get rid of those differentially expressed genes that had no relation to transformation and simply reflected clonal variability of cells.

An observation made at this stage of the work was a strong prevalence of down-regulated over up-regulated genes in the list of candidates. Since p53 is both transcriptional activator and transcriptional repressor, this result argues that loss of p53-dependent transcriptional activation is likely to have stronger impact on the tumorigenic phenotype rather than the release of p53-mediated repression. It also allowed us to focus primarily on identification of candidate tumor suppressors rather than oncogenes. We therefore generated a set of shRNAexpressing constructs against a selected subset of candidates and screened them in Ras transformation assay with the desire to find those that would allow Ras-induced transformation without repression of p53. As we show here, BTG2 appeared to possess all these properties.

BTG2 is an early growth response gene (Bradbury et al. 1991) whose promoter contains p53-binding sites and is regulated by p53 (Rouault et al. 1996). The importance of BTG2 expression in the ability of p53 to resist oncogenic transformation was further demonstrated in the experiments showing that tumorigenic phenotype acquired by cells as a result of BTG2 inactivation and Ras signaling did not require inactivation of p53 itself or its upstream regulator $\mathrm{p} 19^{\mathrm{ARF}}$.

Recently, a BTG2-knockout mouse was generated that appeared to be viable but exhibited abnormalities in ver- tebrae formation during early development (Park et al. 2004). Thus far, BTG2-null mice have not been reported to develop any spontaneous tumors in the early stages of their lives. The absence of sporadic tumor phenotype could be explained by the fact that BTG2 belongs to the class of closely related antiproliferative genes known as the tob family, which includes TOB, TOB2, ANA, PC3B and BTG1 (Matsuda et al. 2001) and which could have a compensatory tumor suppressive effect in BTG2-null mice. Similarly to Rb-deficient mice, where it was demonstrated that only multiple knockouts of $\mathrm{Rb}$ family members made mice prone to spontaneous tumorigenesis (Classon and Harlow 2002), long-term studies as well as interbreeding experiments between knockout members of the tob family are required to uncover their tumor suppressive properties in vivo.

There has been evidence suggesting that BTG2 might be growth suppressive when overexpessed in some tumor cell lines (Montagnoli et al. 1996; Guardavaccaro et al. 2000); however, until now there were no data showing that reduced expression of BTG2 can sensitize cells to the acquisition of tumorigenic phenotype. Here we first demonstrate that shRNA-mediated knockdown of BTG2 in primary human lung fibroblasts IMR-90 abolishes oncogene-mediated growth arrest and allows their proliferation in the presence of hyperactive Ras. Unlike mouse cells, human cells are not completely transformed by the combination of BTG2 knockdown and Ras activation. This is well in line with prior reports indicating that inactivation of p53 is not sufficient to mediate Ras-induced transformation and requires the involvement of oncogenes of DNA containing viruses such as E1A of adenovirus, large and small T-antigens of SV40, and papilloma virus E6/E7-all known to target both p53 and $\mathrm{pRb}$ pathways (Hahn et al. 1999; Morales et al. 1999; Elenbaas et al. 2001). Interestingly, we found that in human cells shRNA-mediated down-regulation of BTG2 results in hyperphosphorylation of $\mathrm{Rb}$ at Ser807, presumably via up-regulation of cyclins D1 and E1 and, in combination with dominant-negative p53 mutant (GSE56), small $\mathrm{T}$ antigene of SV-40, and catalytic subunit of $\mathrm{H}$ TERT, was capable of inducing full transformation of primary human fibroblasts IMR-90. This effect of shRNA against BTG2 was similar to that of shRNA against $p 16$, suggesting that p53-responsive BTG2 is involved in regulation of $\mathrm{Rb}$ pathway, and therefore suppression of BTG2 can cooperate with suppression of p53 in transformation of human fibroblasts. This finding indicates another regulatory link between p53 and $\mathrm{Rb}$ pathways that is mediated by BTG2. However, the need to have both anti-BTG2 shRNA and GSE56 for transformation of human cells might be simply reflect that neither alone can reach strong enough level of inhibition of BTG2.

Recent reports on reduced expression of BTG2 in different sets of human malignancies (Ficazzola et al. 2001; Kawakubo et al. 2004; Struckmann et al. 2004) have been extended by our analysis of a panel of matching tumor and normal tissue samples showing that a large proportion of breast and kidney carcinomas have significantly 
less BTG2 mRNA expression than adjacent normal tissues, thus further confirming relevance of BTG2 deregulation to naturally occurring cancer. Obviously, reduced levels of p53-responsive gene BTG2 in some cancers can be due to p53 inactivation by mutations. This hypothesis, however, cannot explain frequent down-regulation of BTG2 in renal cell carcinoma, the type of cancer that is known to rarely acquire mutations in p53 gene / see the International Agency for Research on Cancer TP53 Mutation Database, http://www.IARC.fr/p53/index.html).

By defining BTG2 as the major player in anti-Ras activity of p53 we have validated the approach we used (consisting of microarray profiling and functional screening in Ras transformation assays) to identify new components of p53 pathway acting downstream of p53. On the other hand, the differences in scales of the effects of BTG2 and p53 knockdowns both in vitro and in transgenic animals suggest that BTG2 is not the only mediator of anti-Ras activity of p53. We therefore believe that the extension of this work toward characterization of the rest of the candidate genes listed in Tables 2 and 3 is important to finds the remaining tumor suppressors of this type.

\section{Materials and methods}

\section{Cells}

Primary MEFs were prepared as described previously (Zou et al. 2002). IMR-90 cells are human diploid embryonic lung fibroblasts that were obtained from American Type Culture Collection.

\section{Recombinant retro- and lentiviral vectors}

The plasmid-encoding dominant-negative inhibitor of p53, GSE56, was described in Ossovskaya et al. (1996). pLRasSN was generated by inserting full-length cDNA of H-Ras ${ }^{\mathrm{V} 12}$ mutant into pLXSN (Clontech). To generate pL56_Ras plasmid pLXSN vector was used to replace SV40-Neo ${ }^{\mathrm{r}}$ region with a full-length $\mathrm{H}-\mathrm{RAS} \mathrm{v}^{\mathrm{v} 2} \mathrm{CDNA}$, the $5^{\prime}$ end of which was previously ligated to the internal ribosomal entry site (IRES) sequence; GSE56 was then inserted into polycloning site under BamHI and EcoRI sites. To generate lentiviral pLV56_Ras plasmid, the fragment containing GSE56_IRES_Ras was recloned into pLVCMVH4 vector under control of CMV promoter. Lentiviral p53 reporter plasmid, pUST_WafConA_mCMVLacZ, was described previously (Razorenova et al. 2005). To generate H-TERT and st lentiviral constructs, their respective cDNAs (kind gifts of R.A. Weinberg, Whitehead Institute for Biomedical Research, Cambridge, MA) were cloned into lentiviral vector PLVCMVH4.

\section{Retroviral/lentiviral transduction}

For the preparation of retroviral stocks Phoenix-ampho packaging cells (Grignani et al. 1998) were used, while 293 T cells were used for preparation of lentiviral stocks. Cells were transfected with the vectors, using Lipofectamin-Plus reagent (Invitrogen Inc.); in the case of lentivirus, two helper plasmids, pCMV $\Delta$ R8.2 and pVSV-G, were cotransfected along with experimental vector. Supernatants containing infectious viral particles were harvested 24,36 , and 48 h post-transfection, pooled, and filtered.
Infections of exponentially growing cells were performed every $5 \mathrm{~h}$ for $2 \mathrm{~d}$ with various dilutions of virus-containing supernatant supplemented with $4 \mu \mathrm{g} / \mathrm{mL}$ polybrene (Sigma).

\section{Selection and cloning of shRNA oligonucleotides}

PickSI Software was used to select appropriate 19-nucleotide (nt) fragment from the target gene cDNA sequence (homologs in mouse and human) and then to generate 19-nt inverted repeat of the selected sequence. The two fragments were then joined together by the 9-nt spacer TTCAAGAGA and a poly(T) stretch was added at the $3^{\prime}$ end of the resultant 47 -nt oligo as a stop codon for RNA polymerase III. The BamHI and HindIII cohesive ends were added at the $5^{\prime}$ and $3^{\prime}$ ends, respectively. Resulting 64-nt short interfering RNA (siRNA) oligos were synthesized at Integrated DNA Technologies, annealed according to manufacturer's protocol, and cloned into modified pBabe-puromyin vector. This vector contains the RNA polymerase III-dependent $\mathrm{H1}$ RNA promoter cloned into NheI site of the U3 region of the $3^{\prime}$ long terminal repeat (LTR), which was used to drive the expression of the siRNAs. siRNA oligos were cloned into BglII and HindIII sites immediately downstream of H1 RNA prompter. The successful 19-nt target sequences used were shBTG2(1): 5'-TCAACCACAAGATGGACCC; $\operatorname{shBTG2(2):~GGTTCTGGC~}$ TATCGCTGTA-3'; and mp53: $5^{\prime}$-GTACATGTGTAATAGCT CC-3'. p16 was reported in Voorhoeve and Agami (2003); hp53 was described in Brummelkamp et al. (2002).

\section{Western immunoblotting}

Protein lysates preparation, electrophoresis, and blotting followed standard protocol. The following primary antibodies were used: H-Ras (F235), p16 (C-20), p21 (F5, F235), p53 (Pab 246), GSE56 (G59-12), cdk4 (C-22) (Santa Cruz), pRb (14001-A, Pharmingen), Phospho-Rb (Ser795), Phospho-Rb (Ser807/811) (Cell Signaling), cyclin D1(Sc-450), and cyclin E1 (M20, C19).

\section{RNA expression analysis}

Total RNA was extracted using Trizol reagent (Invitrogen) according to the manufacturer's protocol. BTG2 mRNA quantitation was performed using a fluorescence-based real-time RTPCR technology (TaqMan Real-Time PCR) with probe-primers sets for mouse and human BTG2 (ABI Assay-on-Demand FAMMGB probes), according to manufacturer's protocol. p53 and p19ARF mRNA quantitation was performed using semiquantative RT-PCR. The following primers were used: p53 sense: $5^{\prime}$ CCCGAGTATCTGGAAGACAG-3'; p53 antisense: 5'-ATAG GTCGGCGGTTCAT-3'; p19ARF sense: 5'-GTCGCAGGTTCT TGGTCACTGTGA-3'; $1{ }^{\text {ARF }}$ antisense: $5^{\prime}$-CTTCTCAAGAT CCTCTCTAGCCTCAACA-3'.

For Northern blot analysis of GADD45y? Hsp25, Cyclin G1, H-rev107, Par-4, eiF4G3, and GAPDH, $10 \mu \mathrm{g}$ of total RNA was electrophoresed and transferred to the Hybond-NX membrane (Amersham Pharmacia Biotech) according to manufacturer's instructions. RNA blots were hybridized with specific $\mathrm{P}^{32}$ radiolabeled probes for indicated genes in ExpressHyb solution (BD Bioscences Clontech) according to manufacturer's instructions.

\section{Senescence-associated $\beta$-galactosidase assay}

Cells were fixed with $0.5 \%$ glutaraldehyde (Sigma) and incubated in staining solution $\left[1 \mathrm{mM} \mathrm{MgCl}_{2}, 3.3 \mathrm{mM} \mathrm{K}_{4} \mathrm{Fe}(\mathrm{CN})_{6}, 3.3\right.$ $\mathrm{mM} \mathrm{K}_{3} \mathrm{Fe}(\mathrm{CN})_{6}, 0.02 \% \mathrm{NP}-40,0.2 \% \mathrm{X}$-Gal (Sigma) at pH 5.5 at $37^{\circ} \mathrm{C}$. Plates were photographed and results were calculated as the percentage of visible cells that had positive staining (at least five different fields were counted for each plate). 


\section{p53 reporter assay}

For measuring p53 transcriptional activity cells were infected with pUST_WafConA_mCMVLacZ plasmid, seeded on 96-well plates, and treated with p53-inducing agents: Doxorubicin $(250$ $\mathrm{ng} / \mathrm{mL}), 5^{\prime}$-FU $(50 \mu \mathrm{g} / \mathrm{mL})$, MMS $(50 \mu \mathrm{g} / \mathrm{mL})$. $\beta$-Galactosidase activity was measured as previously described (Razorenova et al. 2005).

\section{Acknowledgments}

We thank Peter Chumakov for generous gifts of expression vectors. This work was supported by grants CA60730 and CA75179 from NIH to A.V.G.

\section{References}

Baker, S.J., Markowitz, S., Fearon, E.R., Willson, J.K., and Vogelstein, B. 1990. Suppression of human colorectal carcinoma cell growth by wild-type p53. Science 249: 912-915.

Barradas, M., Monjas, A., Diaz-Meco, M.T., Serrano, M., and Moscat, J. 1999. The downregulation of the pro-apoptotic protein Par-4 is critical for Ras-induced survival and tumor progression. EMBO J. 18: 6362-6369.

Bos, J.L. 1989. ras oncogenes in human cancer: A review. Cancer Res. 49: 4682-4689.

Bradbury, A., Possenti, R., Shooter, E.M., and Tirone, F. 1991. Molecular cloning of PC3, a putatively secreted protein whose mRNA is induced by nerve growth factor and depolarization. Proc. Natl. Acad. Sci. 88: 3353-3357.

Brummelkamp, T.R., Bernards, R., and Agami, R. 2002. A system for stable expression of short interfering RNAs in mammalian cells. Science 296: 550-553.

Burgering, B.M. and Medema, R.H. 2003. Decisions on life and death: FOXO Forkhead transcription factors are in command when PKB/Akt is off duty. J. Leukoc. Biol. 73: 689-701.

Chen, L.C., Dollbaum, C., and Smith, H.S. 1989. Loss of heterozygosity on chromosome 1q in human breast cancer. Proc. Natl. Acad. Sci. 86: 7204-7207.

Classon, M. and Harlow, E. 2002. The retinoblastoma tumour suppressor in development and cancer. Nat. Rev. Cancer 2: 910-917.

Debbas, M. and White, E. 1993. Wild-type p53 mediates apoptosis by E1A, which is inhibited by E1B. Genes \& Dev. 7: 546554.

Diehl, J.A., Cheng, M., Roussel, M.F., and Sherr, C.J. 1998. Glycogen synthase kinase- $3 \beta$ regulates cyclin D1 proteolysis and subcellular localization. Genes \& Dev. 12: 3499-3511.

Donehower, L.A., Harvey, M., Slagle, B.L., McArthur, M.J., Montgomery Jr., C.A., Butel, J.S., and Bradley, A. 1992. Mice deficient for p53 are developmentally normal but susceptible to spontaneous tumours. Nature 356: 215-221.

Dyson, N. 1998. The regulation of E2F by pRB-family proteins. Genes \& Dev. 12: 2245-2262.

el-Deiry, W.S., Tokino, T., Velculescu, V.E., Levy, D.B., Parsons, R., Trent, J.M., Lin, D., Mercer, W.E., Kinzler, K.W., and Vogelstein, B. 1993. WAF1, a potential mediator of p53 tumor suppression. Cell 75: 817-825.

Elenbaas, B., Spirio, L., Koerner, F., Fleming, M.D., Zimonjic, D.B., Donaher, J.L., Popescu, N.C., Hahn, W.C., and Weinberg, R.A. 2001. Human breast cancer cells generated by oncogenic transformation of primary mammary epithelial cells. Genes \& Dev. 15: 50-65.

Eliyahu, D., Michalovitz, D., Eliyahu, S., Pinhasi-Kimhi, O., and Oren, M. 1989. Wild-type p53 can inhibit oncogene-medi- ated focus formation. Proc. Natl. Acad. Sci. 86: 8763-8767.

Ezhevsky, S.A., Ho, A., Becker-Hapak, M., Davis, P.K., and Dowdy, S.F. 2001. Differential regulation of retinoblastoma tumor suppressor protein by G(1) cyclin-dependent kinase complexes in vivo. Mol. Cell. Biol. 21: 4773-4784.

Ficazzola, M.A., Fraiman, M., Gitlin, J., Woo, K., Melamed, J., Rubin, M.A., and Walden, P.D. 2001. Antiproliferative B cell translocation gene 2 protein is down-regulated post-transcriptionally as an early event in prostate carcinogenesis. Carcinogenesis 22: 1271-1279.

Finlay, C.A., Hinds, P.W., and Levine, A.J. 1989. The p53 protooncogene can act as a suppressor of transformation. Cell 57: 1083-1093.

Franza Jr., B.R., Maruyama, K., Garrels, J.I., and Ruley, H.E. 1986. In vitro establishment is not a sufficient prerequisite for transformation by activated ras oncogenes. Cell 44: 409418.

Greig, R.G., Koestler, T.P., Trainer, D.L., Corwin, S.P., Miles, L., Kline, T., Sweet, R., Yokoyama, S., and Poste, G. 1985. Tumorigenic and metastatic properties of 'normal' and rastransfected NIH/3T3 cells. Proc. Natl. Acad. Sci. 82: 3698 3701.

Grignani, F., Kinsella, T., Mencarelli, A., Valtieri, M., Riganelli, D., Lanfrancone, L., Peschle, C., Nolan, G.P., and Pelicci, P.G. 1998. High-efficiency gene transfer and selection of human hematopoietic progenitor cells with a hybrid EBV/retroviral vector expressing the green fluorescence protein. Cancer Res. 58: 14-19.

Guardavaccaro, D., Corrente, G., Covone, F., Micheli, L., D'Agnano, I., Starace, G., Caruso, M., and Tirone, F. 2000. Arrest of G(1)-S progression by the p53-inducible gene PC3 is $\mathrm{Rb}$ dependent and relies on the inhibition of cyclin D1 transcription. Mol. Cell. Biol. 20: 1797-1815.

Hahn, W.C. and Weinberg, R.A. 2002. Rules for making human tumor cells. N. Engl. J. Med. 347: 1593-1603.

Hahn, W.C., Counter, C.M., Lundberg, A.S., Beijersbergen, R.L., Brooks, M.W., and Weinberg, R.A. 1999. Creation of human tumour cells with defined genetic elements. Nature 400: 464-468.

Hahn, W.C., Dessain, S.K., Brooks, M.W., King, J.E., Elenbaas, B., Sabatini, D.M., DeCaprio, J.A., and Weinberg, R.A. 2002. Enumeration of the simian virus 40 early region elements necessary for human cell transformation. Mol. Cell. Biol. 22: 2111-2123.

Hajnal, A., Klemenz, R., and Schafer, R. 1994. Subtraction cloning of H-rev107, a gene specifically expressed in $\mathrm{H}$-ras resistant fibroblasts. Oncogene 9: 479-490.

Harbour, J.W., Luo, R.X., Dei Santi, A., Postigo, A.A., and Dean, D.C. 1999. Cdk phosphorylation triggers sequential intramolecular interactions that progressively block $\mathrm{Rb}$ functions as cells move through G1. Cell 98: 859-869.

Hemann, M.T., Zilfou, J.T., Zhao, Z., Burgess, D.J., Hannon, G.J., and Lowe, S.W. 2004. Suppression of tumorigenesis by the p53 target PUMA. Proc. Nat1. Acad. Sci. 101: 9333-9338.

Hermeking, H. and Eick, D. 1994. Mediation of c-Myc-induced apoptosis by p53. Science 265: 2091-2093.

Hunter, T. 1997. Oncoprotein networks. Cell 88: 333-346.

Inoue, K., Wen, R., Rehg, J.E., Adachi, M., Cleveland, J.L., Roussel, M.F., and Sherr, C.J. 2000. Disruption of the ARF transcriptional activator DMP1 facilitates cell immortalization, Ras transformation, and tumorigenesis. Genes \& Dev. 14: 1797-1809.

Jacobs, J.J., Kieboom, K., Marino, S., DePinho, R.A., and van Lohuizen, M. 1999. The oncogene and Polycomb-group gene bmi-1 regulates cell proliferation and senescence through the ink4a locus. Nature 397: 164-168. 
Kamijo, T., Zindy, F., Roussel, M.F., Quelle, D.E., Downing, J.R., Ashmun, R.A., Grosveld, G., and Sherr, C.J. 1997. Tumor suppression at the mouse INK4a locus mediated by the alternative reading frame product p19ARF. Cell 91: 649-659.

Kannan, K., Amariglio, N., Rechavi, G., and Givol, D. 2000. Profile of gene expression regulated by induced p53: Connection to the TGF- $\beta$ family. FEBS Lett. 470: 77-82.

Kawakubo, H., Carey, J.L., Brachtel, E., Gupta, V., Green, J.E., Walden, P.D., and Maheswaran, S. 2004. Expression of the NF-кB-responsive gene BTG2 is aberrantly regulated in breast cancer. Oncogene 23: 8310-8319.

Khwaja, A., Rodriguez-Viciana, P., Wennstrom, S., Warne, P.H., and Downward, J. 1997. Matrix adhesion and Ras transformation both activate a phosphoinositide $3-\mathrm{OH}$ kinase and protein kinase B/Akt cellular survival pathway. EMBO J. 16: $2783-2793$.

Koff, A., Cross, F., Fisher, A., Schumacher, J., Leguellec, K., Philippe, M., and Roberts, J.M. 1991. Human cyclin E, a new cyclin that interacts with two members of the CDC2 gene family. Cell 66: 1217-1228.

Kuo, M.L., Duncavage, E.J., Mathew, R., den Besten, W., Pei, D., Naeve, D., Yamamoto, T., Cheng, C., Sherr, C.J., and Roussel, M.F. 2003. Arf induces p53-dependent and -independent antiproliferative genes. Cancer Res. 63: 1046-1053.

Land, H., Parada, L.F., and Weinberg, R.A. 1983. Tumorigenic conversion of primary embryo fibroblasts requires at least two cooperating oncogenes. Nature 304: 596-602.

Levine, A.J. 1997. p53, the cellular gatekeeper for growth and division. Cell 88: 323-331.

Lim, I.K., Lee, M.S., Ryu, M.S., Park, T.J., Fujiki, H., Eguchi, H., and Paik, W.K. 1998. Induction of growth inhibition of 293 cells by downregulation of the cyclin $\mathrm{E}$ and cyclin-dependent kinase 4 proteins due to overexpression of TIS21. Mol. Carcinog. 23: 25-35.

Lin, A.W. and Lowe, S.W. 2001. Oncogenic ras activates the ARF-p53 pathway to suppress epithelial cell transformation. Proc. Natl. Acad. Sci. 98: 5025-5030.

Lin, A.W., Barradas, M., Stone, J.C., van Aelst, L., Serrano, M., and Lowe, S.W. 1998. Premature senescence involving p53 and p16 is activated in response to constitutive MEK/MAPK mitogenic signaling. Genes \& Dev. 12: 3008-3019.

Lowe, S.W., Cepero, E., and Evan, G. 2004. Intrinsic tumour suppression. Nature 432: 307-315.

Malkin, D. 1994. p53 and the Li-Fraumeni syndrome. Biochim. Biophys. Acta 1198: 197-213.

Matsuda, S., Rouault, J., Magaud, J., and Berthet, C. 2001. In search of a function for the TIS21/PC3/BTG1/TOB family. FEBS Lett. 497: 67-72.

Matsushime, H., Ewen, M.E., Strom, D.K., Kato, J.Y., Hanks, S.K., Roussel, M.F., and Sherr, C.J. 1992. Identification and properties of an atypical catalytic subunit (p34PSK-J3/cdk4) for mammalian D type G1 cyclins. Cell 71: 323-334.

Melamed, J., Kernizan, S., and Walden, P.D. 2002. Expression of B-cell translocation gene 2 protein in normal human tissues. Tissue Cell 34: 28-32.

Mello, C.C. and Conte Jr., D. 2004. Revealing the world of RNA interference. Nature 431: 338-342.

Meyerson, M. and Harlow, E. 1994. Identification of G1 kinase activity for cdk6, a novel cyclin D partner. Mol. Cell. Biol. 14: 2077-2086.

Montagnoli, A., Guardavaccaro, D., Starace, G., and Tirone, F. 1996. Overexpression of the nerve growth factor-inducible PC3 immediate early gene is associated with growth inhibition. Cell Growth Differ. 7: 1327-1336.

Morales, C.P., Holt, S.E., Ouellette, M., Kaur, K.J., Yan, Y., Wilson, K.S., White, M.A., Wright, W.E., and Shay, J.W. 1999.
Absence of cancer-associated changes in human fibroblasts immortalized with telomerase. Nat. Genet. 21: 115-118.

Newbold, R.F. and Overell, R.W. 1983. Fibroblast immortality is a prerequisite for transformation by EJ c-Ha-ras oncogene. Nature 304: 648-651.

Ohtani, K., DeGregori, J., and Nevins, J.R. 1995. Regulation of the cyclin E gene by transcription factor E2F1. Proc. Nat1. Acad. Sci. 92: 12146-12150.

Ossovskaya, V.S., Mazo, I.A., Chernov, M.V., Chernova, O.B., Strezoska, Z., Kondratov, R., Stark, G.R., Chumakov, P.M., and Gudkov, A.V. 1996. Use of genetic suppressor elements to dissect distinct biological effects of separate p53 domains. Proc. Natl. Acad. Sci. 93: 10309-10314.

Palmero, I., Pantoja, C., and Serrano, M. 1998. p19ARF links the tumour suppressor p53 to Ras. Nature 395: 125-126.

Park, S., Lee, Y.J., Lee, H.J., Seki, T., Hong, K.H., Park, J., Beppu, H., Lim, I.K., Yoon, J.W., Li, E., et al. 2004. B-cell translocation gene $2(\mathrm{Btg} 2)$ regulates vertebral patterning by modulating bone morphogenetic protein/smad signaling. Mol. Cell. Biol. 24: 10256-10262.

Polyak, K., Xia, Y., Zweier, J.L., Kinzler, K.W., and Vogelstein, B. 1997. A model for p53-induced apoptosis. Nature 389: 300-305.

Rangarajan, A., Hong, S.J., Gifford, A., and Weinberg, R.A. 2004. Species- and cell type-specific requirements for cellular transformation. Cancer Cell 6: 171-183.

Razorenova, O.V., Agapova, L.S., Budanov, A.V., Ivanov, A.V., Strunina, S.M., and Chumakov, P.M. 2005. [Retroviral reporter systems for the assessment of activity of stress-induced signal transduction pathways controlled by p53, HIF-1 and HSF-1 transcription factors]. Mol. Biol. (Moscow) 39: 286-293.

Reddy, E.P., Reynolds, R.K., Santos, E., and Barbacid, M. 1982. A point mutation is responsible for the acquisition of transforming properties by the T24 human bladder carcinoma oncogene. Nature 300: 149-152.

Rouault, J.P., Falette, N., Guehenneux, F., Guillot, C., Rimokh, R., Wang, Q., Berthet, C., Moyret-Lalle, C., Savatier, P., Pain, B., et al. 1996. Identification of BTG2, an antiproliferative p53-dependent component of the DNA damage cellular response pathway. Nat. Genet. 14: 482-486.

Ruley, H.E. 1983. Adenovirus early region 1A enables viral and cellular transforming genes to transform primary cells in culture. Nature 304: 602-606.

Seeburg, P.H., Colby, W.W., Capon, D.J., Goeddel, D.V., and Levinson, A.D. 1984. Biological properties of human c-Haras1 genes mutated at codon 12. Nature 312: 71-75.

Serrano, M., Lin, A.W., McCurrach, M.E., Beach, D., and Lowe, S.W. 1997. Oncogenic ras provokes premature cell senescence associated with accumulation of p53 and p16INK4a. Cell 88: 593-602.

Sherr, C.J. 1993. Mammalian G1 cyclins. Cell 73: 1059-1065.

. 1998. Tumor surveillance via the ARF-p53 pathway. Genes \& Dev. 12: 2984-2991.

Struckmann, K., Schraml, P., Simon, R., Elmenhorst, K., Mirlacher, M., Kononen, J., and Moch, H. 2004. Impaired expression of the cell cycle regulator BTG2 is common in clear cell renal cell carcinoma. Cancer Res. 64: 1632-1638.

Tanaka, T.S., Jaradat, S.A., Lim, M.K., Kargul, G.J., Wang, X., Grahovac, M.J., Pantano, S., Sano, Y., Piao, Y., Nagaraja, R., et al. 2000. Genome-wide expression profiling of mid-gestation placenta and embryo using a 15,000 mouse developmental cDNA microarray. Proc. Natl. Acad. Sci. 97: 91279132.

Varnum, B.C., Ma, Q.F., Chi, T.H., Fletcher, B., and Herschman, H.R. 1991. The TIS11 primary response gene is a member of 
Boiko et al.

a gene family that encodes proteins with a highly conserved sequence containing an unusual Cys-His repeat. Mol. Cell. Biol. 11: 1754-1758.

Voorhoeve, P.M., and Agami, R. 2003. The tumor-suppressive functions of the human INK4A locus. Cancer Cell 4: 311319.

Wei, W., Hemmer, R.M., and Sedivy, J.M. 2001. Role of p14(ARF) in replicative and induced senescence of human fibroblasts. Mol. Cell. Biol. 21: 6748-6757.

Weinberg, R.A. 1995. The retinoblastoma protein and cell cycle control. Cell 81: 323-330.

Won, K.A., Xiong, Y., Beach, D., and Gilman, M.Z. 1992. Growth-regulated expression of D-type cyclin genes in human diploid fibroblasts. Proc. Natl. Acad. Sci. 89: 9910-9914.

Xiong, Y., Zhang, H., and Beach, D. 1992. D type cyclins associate with multiple protein kinases and the DNA replication and repair factor PCNA. Cell 71: 505-514.

Yin, C., Knudson, C.M., Korsmeyer, S.J., and Van Dyke, T. 1997. Bax suppresses tumorigenesis and stimulates apoptosis in vivo. Nature 385: 637-640.

Zhan, X., and Goldfarb, M. 1986. Growth factor requirements of oncogene-transformed NIH 3T3 and BALB/c 3T3 cells cultured in defined media. Mol. Cell. Biol. 6: 3541-3544.

Zhao, R., Gish, K., Murphy, M., Yin, Y., Notterman, D., Hoffman, W.H., Tom, E., Mack, D.H., and Levine, A.J. 2000. Analysis of p53-regulated gene expression patterns using oligonucleotide arrays. Genes \& Dev. 14: 981-993.

Zou, X., Ray, D., Aziyu, A., Christov, K., Boiko, A.D., Gudkov, A.V., and Kiyokawa, H. 2002. Cdk4 disruption renders primary mouse cells resistant to oncogenic transformation, leading to Arf/p53-independent senescence. Genes \& Dev. 16: $2923-2934$. 


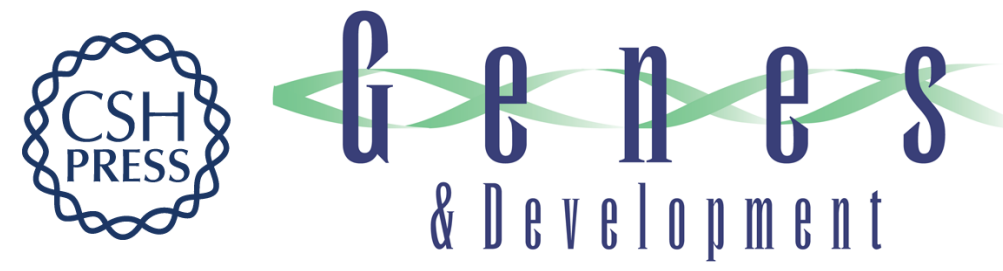

\section{A systematic search for downstream mediators of tumor suppressor function of p53 reveals a major role of BTG2 in suppression of Ras-induced transformation}

Alexander D. Boiko, Sarah Porteous, Olga V. Razorenova, et al.

Genes Dev. 2006, 20:

Access the most recent version at doi:10.1101/gad.1372606

Supplemental http://genesdev.cshlp.org/content/suppl/2005/12/29/20.2.236.DC1

Material

References This article cites 79 articles, 37 of which can be accessed free at: http://genesdev.cshlp.org/content/20/2/236.full.html\#ref-list-1

License

Email Alerting Receive free email alerts when new articles cite this article - sign up in the box at the top Service right corner of the article or click here.

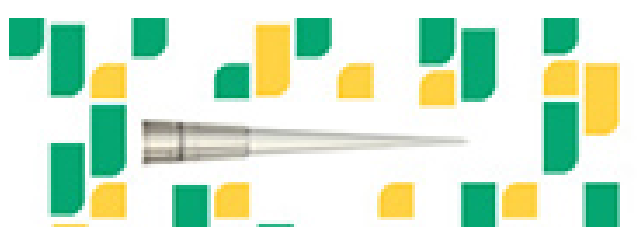

Focused on your science. 